\title{
2018 Cumhurbaşkanlığı Seçimleri Bağlamında Siyasal Reklamlar, Twitter ve Haber Gündemi Benzerlik Analizi
}

\author{
DOI: 10.26466/opus.522288 \\ * \\ $\underline{\text { Emine Şahin }}^{*}$-Özlem Duğan ${ }^{* *}-$ Adil Bical $^{* * *}$ \\ *Dr. Öğr. Üyesi, Gaziantep Üniversitesi, İletişim Fakültesi, Gaziantep / Türkiye \\ E-Posta: emines@gantep.edu.tr \\ ORCID: 0000-0002-7269-0923 \\ **Dr. Öğr. Üyesi, Uşak Universitesi, İletişim Fakültesi, Uşak/Türkiye \\ E-Posta: ozlem.dugan@usak.edu.tr \\ ORCID: 0000-0001-9028-7989 \\ ***Arş. Gör. Anadolu Üniversitesi, İletişim Bilimleri Fakültesi, Eskişehir / Türkiye \\ E-Posta: adilbical@gmail.com \\ ORCID: 0000-0001-6139-5497
}

Öz

Seçim dönemi adaylar siyasal iletişim çalışmalarında reklam, haber ve sosyal medya paylaşımları gibi tüm iletişim araçlarım kullanarak seçmenlerin gündeminde yer almayı amaçlamaktadır. Kampanyaların başarısı adayların tüm mecralarda aynı zaman diliminde benzer konulara yer vermesine bağhldır. Bu bağlamda gündem oluşturma kuramı kullanılarak, 2018 Cumhurbaşkanlığı seçimlerinde adayların siyasal reklam içerikleri ile, Twitter paylaşımları ve haber sitesinde yayınlanan haberlerin gündem konusu benzerliklerini ortaya koymak amactyla yapılan araştırmada, adaylardan Recep Tayyip Erdoğan, Muharrem Ince, Meral Akşener' in siyasal reklamları, Twitter paylaşımları, dijital mecrada en çok takip edilen haber sitesinin adaylarla ilgili haberleri incelenmiştir. Çalışmada nitel araştırma deseni kullanılmış Nvivo yazılım programı ve kodlayıcılarla kelime ve süre kriterine göre içerik analizi yapılmış, araştırma sorularına cevap aranmıştır. Araştırma sonucunda, siyasal reklamlarda ve Twitter paylaşımlarında Erdoğan'ın milli değerlere Akşener'in ekonomi ve iç politikaya benzer oranda vurgu yaptığına ancak İnce'de benzerliğin olmadığına ulaşılmıştır. Adayların reklam ve haber paylaşımlarındaki konuların benzerliğine bakıldığında Erdoğan'ın ekonomi, bireysel özgürlükler ve eğitim konusunda, İnce'nin ekonomi, göç ve değerler kategorisinde benzerlik bulunmuş ancak Akşener'in reklam ve haber paylaşımlarındaki kategoriler arasında bir benzerlik bulunmamıştır. Tüm mecraların gündem kategorisinde adaylar arasındaki benzerlik incelenmiş Erdoğan ile İnce ve Akşener arasında iç politika ile bireysel özgürlükler kategorisi stralamasında benzerlik olduğu sonucu elde edilmiştir. Göç ve çevre konusu tüm adaylarda son strada yer almaktadır.

Anahtar Kelimeler: Gündem oluşturma, Cumhurbaşkanlığı seçimleri, siyasal iletişim kampanyaları, siyasal reklamlar 


\title{
The Similarity Analysis of Political Advertising, Twitter and News Agenda in the Context of 2018 Presidency Election
}

\begin{abstract}
In times of elections the candidates aim to be on the agenda of voters by using communication tools, as advertisements, news and social media accounts in their political communication endeavours. The success of these campaigns are dependent on the candidates mentioning the same topics in all the channels and in the same time period. In this regard, by using agenda setting theory, in this study which is conducted in order to reveal the similarities of issue agenda during 2018 presidential election candidates' political ads content, their Twitter posts and the news coverage aired in the news websites; the political advertisements, Twitter posts and the news of the most popular news websites of the candidates which are Recep Tayyip Erdoğan, Muharrem Ince and Meral Akşener are examined. In the study, qualitative research design is chosen and with Nvivo software and encoders content analysis is performed used in terms of categorical words and timing; thus searching answers for research questions. The results of the study revealed that in his political advertisements and Twitter posts Erdoğan focused on national values; Akşener focused on economy and domestic policy; however there is no focus on Ince's statements. When the similarity between the candidates' advertisement and news content is analyzed Erdoğan focused on economy, individual liberties and education; Ince focused on economy and national values but there is no focus in Akşener's content. The similarities between the candidates are examined in the category of all channels agenda and it is concluded that there is similarity between the focuses of individual liberties and issue of domestic policy: category between Erdoğan, Ince and Akşener respectively. The topics of immigration and environment are the last on the candidates' list.
\end{abstract}

Keywords: Agenda setting, Presidential elections, political communication campaigns, political advertising 


\section{Giriş}

Seçim dönemlerinde siyasal iletişim çalışmalarına ağırlık veren adaylar kitle iletişim araçlarını bütünleşik olarak kullanarak seçmenleri her yönden kuşatarak etkilemeye çalışmaktadır. Siyasal kampanya stratejileri doğrultusunda bazı konulara öncelik vererek gündemlerine taşımaktadır. Zaman zaman medya ve kamuoyunun gündemi adayların gündemini şekillendirdiği gibi zaman zaman da medya kuruluşları yayın akışlarını kamuoyu ve adayların gündeminde yer alan konulardan faydalanarak oluşturmaktadır. Bu anlamda siyasal iletişim çalışmalarında kullanılan gündem oluşturma kuramı ile, medya ve siyaset arasındaki ilişkiyi, dolaylı yoldan da toplumun gündemini, bu kurumların gündemindeki konular bağlamında irdelenmekte ve birbiri üzerindeki etkisi ortaya koyulmaya çalışılmaktadır. Gündem oluşturma kuramının temelinde, medyanın haberleri görsel ve sıralı olarak sunuş yoluyla, konuya ayırdığ süre ya da sıklık derecesine göre halkın düşündüğü ve konuştuğu konuları belirlediği düşüncesine dayanmaktadır. İlk olarak Kurt Lang ve Gladys E.Lang tarafından ortaya atılan medyanın gündemi oluşturma kuramının Walter Lippmann (1922), Bernard Cohen (1963) gibi araştırmacıların katkılarının yanı sıra öncüleri Amerikalı araştırmacılar Malcom McCombs ve Donald Shaw olmuştur (Yumlu, 1994; Yaşin, 2008; Yaylagül, 2014; Yüksel, 2007).

Gündem oluşturma kuramı doğrultusunda yapılan araştırmalarda reklam gündemi ile kamu gündemi arasında ilişkinin ortaya konulduğu (Min, 2003), siyasal reklamların belirli dönemde gazete ve belirli dönemde de yerel televizyon kanallarının haber gündemlerini oluşturduğu (Roberts ve McCombs, 1994, s. 261) belirlenmiştir. Bazı araştırmalarda siyasal reklamların gündemleri ile sosyal medya ve haber kanallarının gündemleri arasındaki ilişki ortaya konmaktadır (Lopez-Escobar, Llamas, McCombs vd.,1998; Roberts, Wanta ve Dzwo, 2002; Sweetser, Golan ve Wanta, 2008). Türkiye'de kuram kapsamında yapılan araştırmalar incelendiğinde yurt dışındaki araştırmalara paralel olarak özellikle medyanın uygun gördüğü sosyal, ekonomik ve politik konuları biçimsel olarak ele alış şekli ve konuların medyada işleniş sıklığı, medyanın politik gündem belirlemede rolü, medya kullanım düzeyi, farklı değişkenlere göre ele alınmıştır (Terkan, 2007; Yüksel, 2007; Toruk, 2008; Bozkanat, 
2013; Arklan ve Karakoç, 2015; Balcı vd., 2016; Kuyucu, 2016; Bayram, 2017; Geçer ve Şimşek, 2017, Acar-Şentürk ve Tos, 2018). Ancak Türkiye'de seçim dönemlerinde medyanın konu edindiği ve izleyicilerine sunduğu haber içerikleri ile reklam içerikleri arasındaki etkiyi ortaya koyan bir çalışmaya rastlanmamıştır. Bu nedenle çalışmada 2018 Cumhurbaşkanlığı seçim sürecinde adayların kampanyalarındaki reklam mesajlarının içerikleri ile Twitter paylaşımları, haber sitesinde yayınlanan haberlerin içeriklerinin benzerliklerini ortaya koymak amacıyla araştırmacılar tarafından belirlenen sorulara cevap aranmıştır. Seçimlerde adaylardan Recep Tayyip Erdoğan, Muharrem İnce ve Meral Akşener'in siyasal iletişim çalışmaları içinde siyasal reklamları, Twitter paylaşımları ve dijital mecrada en çok takip edilen haber sitesinin adaylarla ilgili haberleri 1 Nisan-24 Haziran 2018 tarihleri arasında incelenerek içerik analizi yapılmıştır. Adayların Twitter paylaşımlarındaki konu dağılımları, en çok takip edilen haber sitesi Hürriyet'te yayınlanan haber konularının dağılımları ve adayların siyasal reklamlarındaki konu dağılımları arasındaki ilişki ortaya konulmaya çalışılmıştır..

\section{Gündem Oluşturma Kuramı}

Gündem oluşturma İngilizcede "agenda setting" olarak isimlendirilmektedir. Gündem belirleme, farklı kaynaklar tarafından gündem yaratma, gündem oluşturma, gündem kurma ve gündem hazırlama gibi farklı kavramlarla da ifade edilmektedir (Yüksel, 2007, s.576-578). İlk olarak Kurt Lang ve Gladys E.Lang tarafından ortaya atılan medyanın gündemi belirleme kuramının daha sonraki öncüleri Amerikalı araştırmacılar Malcom McCombs ve Donald Shaw olmuştur (Yumlu, 1994, s. 96; Yaşin, 2008, s.5; Yaylagül, 2014, s.79). Bunun yanı sıra gündem oluşturma kuramının düşünsel temelinde Walter Lippmann tarafından 1922 yılında kaleme alınan "Public Opinion" (Kamuoyu) isimli çalışması da yer almaktadır. Gündem oluşturma kuramının fikir öncüsü Lippmann 1920'li yıllarda medyanın güçlü etkileri olduğunu ileri sürmüş ve 1960'lı yıllarda yapılan etki ağırlıklı araştırmalara öncülük etmiştir. Ona göre kitle iletişim araçları bireyin dış dünyasındaki gerçekleri şekillendirmektedir ve zihinlerindeki farklı sembolik görüntüleri inşa etmektedir (Hawks, 2002, s.492). Diğer bir 
araştırmacı Bernard Cohen 1963 yılındaki çalışmalarıyla kuramın oluşturulmasına katkı sağlamıştır. Cohen 1963'te "Medya ne düşüneceğimizi söylemekte başarılı olmayabilir, fakat ne hakkında düşüneceğimizi söylemekte fevkalade başarılıdır" (akt. McCombs ve Yüksel, 2001, s. 153) ifadesiyle toplum üzerinde kitle iletişim araçlarının etkisini ortaya koymuştur. McCombs ve Shaw'in (1972) Amerika Birleşik Devletleri'ndeki 1968 Başkanlık seçimleri örnekleminde kitle iletişim araçlarının gündem oluşturma gücünü ölçmeyi amaçlayan çalışmaları ilk olurken, devam eden zamanlarda çok sayıda araştırma yer almaktadır (Becker ve McCombs, 1978; Miller ve Wanta, 1992; Bryant and Zillman 1994 akt Hawks, 2002; Jasperson, Shah, Watts vd., 1998; van Praag Jr ve Eijk, 1998; Woodly, 2007; Vargo, Guo, MacCombs ve Shaw, 2014). Kuramin bu günkü anlamda geliştirilmesini sağlayan McCombs ve Shaw bireylerin kitle iletişim araçları sayesinde elde ettikleri bilgileri değerlendirip olay ya da haberlerin toplumda önemine dair bir fikir edinerek kendi ilgi alanlarını oluşturdukları yargısını savunmaktadır (Güngör, 2011, s. 98).

Medya, siyaset, kamuoyu ilişkisini açıklamada önemli bir yol gösterici olarak kabul edilen gündem belirleme kuramı ile (Terkan, 2005, s. 15) kamu, medya ve siyaset arasındaki ilişki, bu kurumların gündemindeki konular bağlamında irdelenmekte ve birbiri üzerindeki etkisini ortaya koymaya çalışmaktadır. Teoriyle ilgili olarak medyanın insanlar üzerindeki etkisinden söz edildiğinde, gündem oluşturma teorisi ile bireylerin bir şeyi fark etme ve bir şeye ilişkin haberlere ulaşma derecesini, bilişsel düzeyde insanların haberlerden etkilenme düzeyi ile devam ettiğini ifade etmektedir (Güneş, 2014, s. 3; Jasperson vd.,1998, s. 220). Sürecin devamında ortaya çıkması beklenen habere ya da mesaja maruz kalan izleyici-dinleyicilerde tutum ve davranış değişikliğidir (Yüksel, 2007, s.571). Medya gündemi nitel araştırma deseni tercih edilerek içerik analizi/framing ile belirlenirken kamu gündemi alan araştırmasında elde edilen anket sonuçları ile ortaya konmaktadır ya da kitle iletişim araçları, politikacılar ve kamuoyunun gündemi arasındaki ilişkiyi ortaya koymak için bütünleşik yöntemler uygulanmaktadır. Ancak zaman zaman da kitle iletişim araçlarında haber kuşaklarında yer edecek kadar önemli görülen konular kamuoyu tarafından ilgi duyulan olaylardan oluşmaktadır. Gündemlerin her biri birbirlerini etkileme gücüne sahip olabilmektedir. 
Medyanın gündem oluşturma süreci üç ana aşamaya indirgenmektedir. Gerçek gündem; medya gündemi, kamu gündemi ve siyasal gündemin birbiriyle ilişkili olduğu ifade edilmektedir (McQuail ve Windahl, 2010, s.137; Yüksel, 2001, s. 29). Medya, sahip olduğu otorite ve dikkat çekme özelliği ile kamu gündemini direkt olarak etkileyebilmektedir. Günümüzde kullanım ağının fazla olması ya da toplum düzeyinde kullanım oranı etkinin artmasını sağlamaktadır. Kamu gündemi; söz konusu seçimler iken seçmenlerin talep ve beklentileri politika gündemini etkileyebilmektedir. Yine medya gündemi; kamuoyunu etkileme amac1 güden politikacıların medyayı rehber olarak kullanmasıyla politika gündemini etkileyebilmektedir. Bazı konularda siyasal gündem medya gündemi üzerinden doğrudan ve kuvvetli bir etkide bulunmaktadır. Politika ve medya gündemleri kanaat önderlerinin kitlelerin fikirlerini yönlendirmesi sonucu dolaylı olarak kamu gündemini etkileyebilmektedir (McQuail ve Windahl, 2010, s. 136-137). Rogers ve Dearing tarafından 1987 yılında ortaya konan bir model ile tanımlanmaya çalışılmıştır (Şekil $1)$.

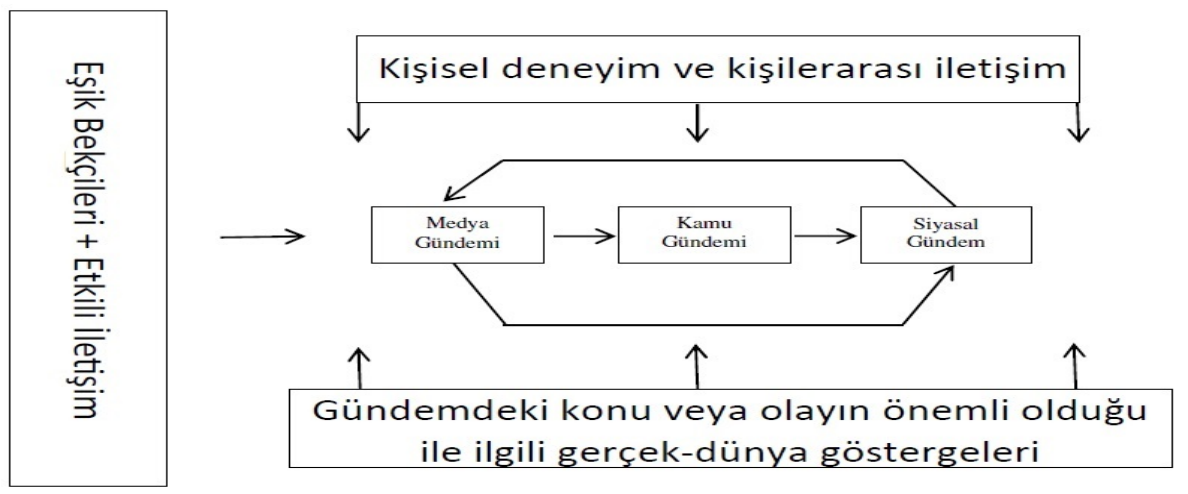

Şekil 1. Gündem Oluşturma Modeli

Kaynak: McQuail ve Windahl, 2010, s. 137.

Günümüzde medya, kamuoyuna sadece işlenen konuların önemleri hakkında karar vermelerine değil, ayrıca bu konular hakkında nasıl hissetmeleri gerektiği konusunda da yardımcı olmaktadır. Gündem oluşturma teorisinin ilk çıkış manifestosu "medya ne düşünmemizi 
söylemeyebilir ama bize ne hakkında düşünmemiz gerektiğini söylemekte oldukça başarılıdır" iken bu günümüzde "medya bize bazı konular hakkında nasıl düşünmemiz gerektiğini söyler"e çevrilmiştir (Lilleker, 2013, s. 37; Yaylagül, 2014, s. 78; Yakubu, 2015, s. 15-16). Medyanın gündem oluşturma gücünün bir yansıması olarak medyanın önem verdiği konular toplumu oluşturan bireyler tarafından daha fazla tanınmakta, üzerinde daha fazla konuşularak tartışılmaktadır. Ancak medyanın önem vermediği ya da geri plana iterek önemsiz göstermeye çalıştığ her türlü konu toplumun gözündeki önemini yitirerek geri planda kalacak ve unutulacaktır. Başka bir ifadeyle, medyada en çok ilgi gören konu, kamu tarafından önemli olarak algilanmaktadır (Kuyucu, 2016, s. 328). Kitle iletişim araçları, toplumda meydana gelen olayları aktarırken her ne kadar tarafsız oldukların iddia etseler de belli bir siyasal görüş doğrultusunda bazı haberleri daha çok önemsemekte, ön plana çıkarmakta, daha fazla yer vermekte ve sürekli gündeme getirmektedir.

Özellikle ekonomik ve siyasi faktörlerin gündemi belirlemedeki gücünün farkında olan toplumsal hareket ve çıkar grupları savundukları konuların kendilerinin bakış açısına göre kabul edilmesi için çaba sarf etmektedir. Bu nedenle kendi düşüncelerini destekleyecek kişi ve kurumlara ulaşma, işbirliği yapma, medyada yer alma gibi nedenlerle gündem oluşturmak yönünde faaliyetlerde bulunmaktadır (Güran ve Özarslan, 2013, s. 309). Medyanın kamuoyu üzerindeki etkisini fark eden siyasiler medyayı kullanarak etki oluşturmayı amaçlamaktadır. Özellikle de seçim dönemlerinde daha yoğun kullanılan kitle iletişim araçları ile siyasiler seçim politikalarını seçmenlere aktarmakta, seçim stratejisi kapsamında imaj oluşturmada kitle iletişim araçlarını kullanmaktadır. Medyanın kamuoyunun gündemini belirleme gücü özellikle seçim dönemlerinde artmaktadır. Seçim kampanyalarının yoğunluk kazandığı dönemlerde medya kuruluşları seçim politikalarını paylaşan siyasi açısından önemli olduğu kadar seçmenler açısından da önemlidir. Bu dönem seçmenin etkilenmeye en fazla açık olduğu dönemdir (Güz, 2005, s. 5152). Seçmenler modern yaşamla birlikte gündelik hayatta daha çok zaman ayırdıkları kitle iletişim araçlarından bilgi edinmektedir. Medya kuruluşunun seçim zamanı adayların iletişim çalışmalarını izleyiciye aktarmada uyguladığı öncelik sırası, ayrılan süre, görsel ve yazılı iletişim unsurlarının kullanımı önem taşımaktadır (Atabek, 1998, s. 157). Aynı ya 
da benzer temaların veriliş sıklığı gibi faktörler izleyiciler için hem konunun önem derecesini belirlemelerini hem de konuyu hatırlamalarını sağlamaktadır.

Türkiye'de teori kapsamında yapılan çalışmalar daha çok siyasal gündem oluşturma odağında devam etmektedir (Yaşin, 2008, s. 7). Bu alanda yapılan araştırmalar incelendiğinde yurt dışındaki araştırmalara paralel olarak medyanın konuları biçimsel olarak ele alış şekli ve konuların medyada işleniş sıklığı, medyanın politik gündem belirlemedeki rolü, medya kullanım düzeyi gibi konuların farklı değişkenlere göre ele alındığ1 tespit edilmştir (Terkan, 2005; Yüksel, 2007; Toruk, 2008; Bozkanat, 2013; Arklan ve Karakoç, 2015; Balcı vd., 2016; Kuyucu, 2016; Bayram, 2017; Geçer ve Şimşek, 2017, Acar-Şentürk ve Tos, 2018). Terkan yaptığı çalışmada (2007) medyanın, bir konunun önem derecesi ile ilgili algiların ve kişisel gündemlerin şekillenmesini çerçeveleme ve öne çıkarma yoluyla sağladığını ortaya koyarken Yüksel (2007) literatürden faydalanarak kavramsal ve kuramsal düzeyde teoriye açıklama getirmektedir. Toruk'un (2008) araştırmasında Türk gençliğinin medyayla yakından ilgilendiğini, medyadan etkilendiği ve bilgilendiği ortaya konmaktadır. Bozkanat (2013) çalışmasında gazeteleri inceleyerek Türkiye'deki alkol düzenleme yasasına yönelik haberlerin toplumla paylaşımında gazetelerin kendi ideolojilerinden hareketle, kanaatlerini okuyucuda inşa etmek için kelime seçimlerini yaptıklarını ortaya koymaktadır, benzer bir çalışma da Acar Şentürk ve Tos (2018) tarafından yapılmıştır. Arklan ve Karakoç (2015) yapmış oldukları çalışmada üniversite gençliğinin siyasal gündeme ilişkin bilgi edinmede kullanım düzeyi açısından internetin, güven ve etkilenme düzeyi açısından ise gazetenin diğer kitle iletişim araçlarından daha yüksek düzeyde olduğunu ortaya koymuştur. Balcı vd'nin (2016) araştırmasında katılımcıların internet ve sosyal medyayı siyasal bilgilenme sürecinde en etkili iki iletişim aracı olarak gördükleri ortaya çıkmıştır. Kuyucu'nun (2016) araştırmasında üniversitede eğitim gören gençlerin radyodan müzik dinledikleri ama müzik zevklerinin radyodan gelen mesajlardan çok kendi bireysel seçimleri ile şekillendiği sonucuna ulaşılmıştır. Bayram'ın (2017) çalışması sonucunda gençlerin gelenekselden çok internet tabanlı enformasyon kaynaklarından siyasal gündemi takip ettikleri, siyasal tutum geliştirme noktasında ise ge- 
leneksel enformasyon kaynakları ve birincil ilişkilerin geçerli olduğu ortamlara daha bağlı kaldıkları bilgisine ulaşılmıştır. Ayrıca Geçer ve Şimşek (2017) sinema filmi Başkanın Adamları ve Kriz Bizim İşimiz örnekleminde medyanın nasıl kamu gündemini etkilediğini ortaya koymaktadır.

Diğer taraftan yeni medyanın yoğun kullanımı ile birlikte reklamların ilgili platformlarda tartışılması, kullanıcıların kendi sayfalarında beğendikleri reklamları paylaşması ile reklamların kamuoyunun gündeminde kalması ve reklamların içeriğinin izleyicilerce tartışılması sağlanmaktadır (Hazaparu, 2014, s. 331). Yine anneler günü, sevgililer günü, milli ve dini bayramlar gibi özel günleri konu alan yaratıcı ve tüketicilerin beğenisine hitap eden reklamların izleyicilerin gündeminde konu edinme düzeyinde önemli rolü olduğu bilinmektedir (Şahin ve Acar Şentürk, 2018). Bazen de reklamcılar kitle iletişim araçlarının gündemini mizah yada ironi unsuru katarak reklam mesajına çevirmektedir. Örneğin IKKEA markasının Türkiye'de şiddetli dolunun araçlarına zarar vermesinden korkan vatandaşların evlerinden çıkardıkları kilimleri otomobillerinin üzerine örttüğü haberlerinin sosyal medya reklamlarında kullanması gibi (Geçtiğimiz Hafta Yağmak Bilmeyen 'Dolu'. 2018).

Sutherland ve Galloway (1981, s. 26) medya gündemlerinin kamu gündemleri haline gelme sürecini açıklamak için reklamcılıkla gündem oluşturma arasındaki paralelliğin ortaya konmasının önemli olduğunu vurgulamaktadır. Onlara göre reklam stratejisi gündem oluşturma teorisinin çıkış noktası ile benzerlik taşımaktadır. Reklamcılığın ana amacı, ikna etmeye çalışmak yerine tüketicilerin dikkatini ürün ya da markanın değerlerine çekmek ya da ürünlerin/markaların özellikleri üzerinde düşünmeye odaklanmasını sağlamaktır. Markalar da zaman zaman kamuoyunun gündemini belirlemektedir. Marka iletişimi kapsamında firmaların sosyal medyada kullanıcı sayfalarında paylaştıkları içerikler bir anda takipçilerin hakkında konuştukları konular olmaktadır (Aslan, 2014). Bu şekliyle Rogers ve Dearing'in modeline farklı bir boyut kazandıran Arslan'ın (2014, s.163) gündem belirleme sürecini oluşturan 3 aşamaya dördüncü bir aşamayı eklediği görülmektedir (Şekil 2). 


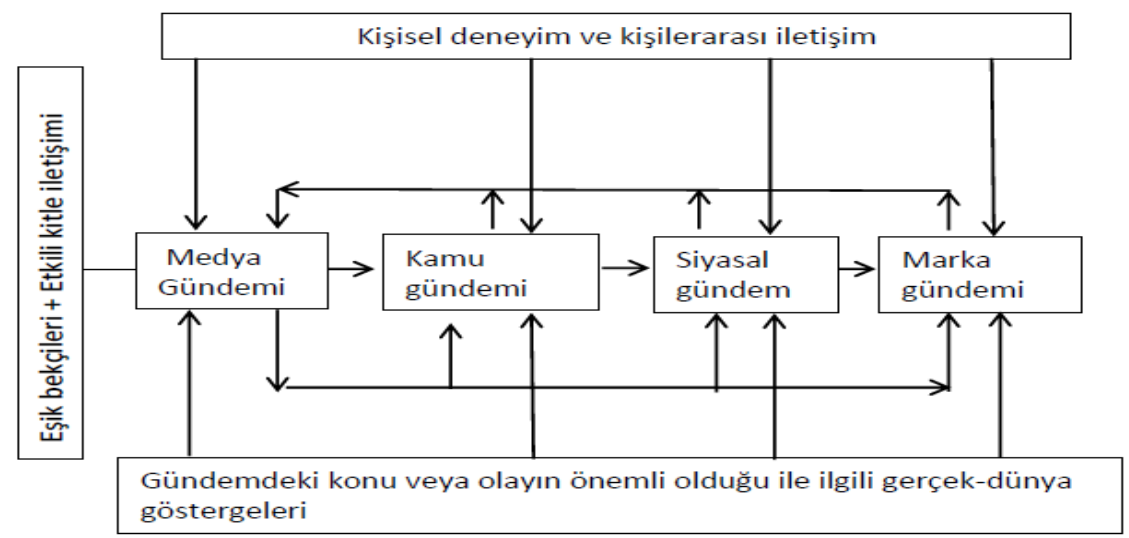

Şekil 2. Gündem Oluşturma Modelinin Geliştirilmiş Şekli

Kaynak: Arslan, 2014, s. 163

Modelde marka gümdemi diğer gündemlerden hem etkilenmekte hem de medya gündemini etkilemektedir.

\section{Siyasal Reklamlar ve Gündem Oluşturma}

Siyasal iletişimde temel amaç adayın seçmenleri ile iletişim kurmasını sağlamak, seçmenleri üzerinde iyi algı oluşturmak ve onlar lehinde oy kullanmaya ikna etmek olduğunda pazarlama iletişimi çabalarına giren adaylar diğer iletişim araçlarının yanı sıra reklamlardan da faydalanmaktadır. Seçim dönemi tüm iletişim uygulamalarında ortak mesaj paylaşımı yapmak diğer bir ifadeyle seçim kampanyası boyunca yürütülen tüm iletişim aktivitelerinde kullanılan mesajlarda konu bütünlügünün olması beklenmektedir. Etkili bir kampanya yürütülmesinde partinin ya da adayın seçim politikasının seçmenlere aktarmasından sonuç öngörülerinin paylaşılmasına kadar yoğun seçim maratonu içinde her iletişim çabası gündeminin seçmenleri etkilediği düşünüldüğünde konu benzerliği daha da önem kazanmaktadır. Bu doğrultuda seçmenlerle birebir iletişim kurmak kadar iyi bir seçim kampanyası stratejisi belirlemek, geleneksel ve elektronik mecraları bu doğrultuda çok iyi kullanmak gerekmektedir.

Yazılı ve elektronik basında haber konusu ya da program konuğu olarak yer almanın yanı sıra konu akışını belirlemek kısmen parti iletişim 
koordinatörlerinin ve medya kuruluşlarının kontrolündeyken sosyal medya hesaplarının kontrolü ve siyasal reklamların içeriği çoğunlukla adaylar tarafından belirlenmektedir. Siyasal kampanya bünyesinde sosyal medya uzmanı olarak görev yapan çalışanlar aday ya da partinin Facebook, Twitter, Instagram gibi sosyal medya hesapların kontrol etmekte siyasal kampanya sürecinde mesaj stratejileri doğrultusunda bu uygulamalarda mesaj paylaşmaktadır. Aynı zamanda reklamlar partinin seçim politikasını yaymak, seçmeni ikna etmek, tutum geliştirmek ya da destekleme davranışı geliştirmek amacıyla propaganda aracı olarak kullanılmaktadır. Dünyada siyasal reklamlar 1952 yılından sonra ABD'de her seçim kampanyasında kullanılır duruma gelirken (Tokgöz, 2014, s. 173), Türkiye'de ise 1977 seçimlerinde Adalet Partisi'nin propaganda çalışmalarında ilk defa kullanılmış ve 1983 yılında gerekli yasal düzenlemelerin yapılmasıyla yasal olarak kullanımı sağlanmıştır (Balcı ve Bal, 2007, s. 6).

Siyasal reklamlar siyasal parti ve adayların seçim kampanyası boyunca seçmenleri etkilemek ve bilgilendirmek bakımından her zaman yararlandıkları tutundurma araçlarından biri olarak görülmektedir. Kampanya gündeminin oluşturulmasında siyasal reklamların kullanımı seçim başarısı için önemli bir faktördür (Balc1 ve Bal, 2007, s. 8). Dolayısıyla siyasal reklamların planlanması ve uygulanması reklamın doğasına uygun olarak şekillenen güçlü iletişim içeren yaratıcı pazarlama tekniklerini gerektirmektedir. Reklamcılar siyasal parti kampanyası boyunca bir taraftan aday imajı oluşturma bir taraftan da bilişsel düzeyde seçim politikalarını halkla paylaşma çabasına girmektedir. Geçmiş dönemde siyasal reklamları pozitif/negatif, konu/imaj ${ }^{1}$, açı/örtülü marjinal olarak sinıflandırıldığ1 ve politik tutum oluşturmada etkisini konu alan araştırmalara rastlanmaktadır (Kaid ve Johnston, 1991; Min, 2003, Kaid, Postelnicu, Landreville, Yun ve LeGrange., 2007; Balc1 ve Bal, 2007; Vodinalı ve Akıncı Çötak, 2015; Meirick, Nisbett, Harvell-Bowman vd. 2018). Min, (2003, s. 126-28) TV reklamlarında mesajın veriliş şeklinin reklam gündemi ile kamu gündemi arasında ilişkiyi ortaya koymada belirleyici olduğunu vurgulamıştır. Araştırmasında negatif mesaj taşıyan siyasal

\footnotetext{
${ }^{1}$ Imaj reklamı seçmenlerin parti hakkında algılarını değiştirmeye yönelik algısını değiştirmeye ya da var olan iyi algıyı devam ettirmeye yönelikken konu reklamı mevcut sorunlar, konular, ya da olay karşısında aday ya da parti ya da adayın tutumu (Balcı ve Bal, 2007, s. 8)
} 
reklamların gündem oluşturmada haber kanallarından daha etkili olduğu belirlenmiştir. Rahn ve Hirshorn (1999, s. 403-405) negatif reklam mesajına maruz kalan gençlerin siyasi tutumlarının değiştiğini ancak bunun seçime katılma tercihlerini etkilemediğini belirlemiştir. Aksine negatif reklam mesajlarına maruz kalan siyasete ilgisi yüksek genç seçmenler siyasi tercihlerini daha güçlü savunmaktadır. Kaid vd., (2007, s.1148) seçmenlerin siyasi reklamlardan Bush'un imajı ve Kerry'in sorunlara yaklaşımına yönelik bilgi edindiğini ve siyasal reklamlara maruz kalmanın kadınların gündemini daha çok etkilediğini ortaya koymaktadır.

Siyasal reklamlar yalnızca seçmenlerin değil diğer kitle iletişim araçlarının gündemini etkilemekte ve zaman zaman onlardan etkilenmektedir. Alan yazın taramasında ilk defa Roberts ve McCombs (1994) siyasal reklamların diğer mecraların gündemini belirlemedeki rolünü ortaya koymaktadır. Araştırmacılar 1990'da Teksas'taki hükümet seçimlerinde kullanılan siyasal reklamların belirli dönemde gazete ve belirli dönemde de yerel televizyon kanallarının haber gündemlerini oluşturduğunu belirlemişlerdir (Roberts ve McCombs, 1994, s. 261). Benzer araştırmalarda iki aşamalı gündem belirleme teorisi kullanılarak siyasal reklamların gündemleri ile sosyal medya ve haber kanallarının gündemleri arasındaki ilişki belirlenmeye çalışılmıştır (Lopez-Escobar, Llamas, McCombs vd. 1998; Roberts, Wanta ve Dzwo, 2002; Sweetser, Golan ve Wanta, 2008). Ancak Türkiye'de seçim dönemlerinde medyanın konu edindiği ve izleyicilerine sunduğu medya içerikleri ile reklam içerikleri arasındaki benzerliği ortaya koyan bir çalışmaya rastlanmamıştır.

\section{Yöntem}

Yapılan alanyazın taraması sonrasında 2018 Cumhurbaşkanlığı seçimlerinde adayların siyasal reklam içerikleri ile Twitter paylaşımlarının ve haber sitesinde yayınlanan haberlerin konu benzerliklerini ortaya koymak amacıyla şu araştırma sorularına cevap aranmaktadır.

AS1. Adaylarm siyasal reklamlarndaki gündem konularn ile Twitter paylaşımlarındaki gündem konuları arasında benzerlik var mıdır?

AS2. Adaylarm siyasal reklamlarındaki gündem konularn ile yer aldikları siyasal haberlerdeki gündem konuları arasında benzerlik var mıdır? 
AS3. Adayların Twitter paylaşımları ile yer aldıkları siyasal haberlerdeki gündem konuları arasinda benzerlik var midır?

AS4. Adaylar arasında siyasal reklamlar, Twitter paylaşımları, haber sitesinde yayınlanan haber içeriklerinin toplamında gündem konuları arasında benzerlik var midır?

Araştırmada 2018 Cumhurbaşkanlığı seçimlerinde adayların siyasal reklamları, Twitter paylaşımları ve dijital mecrada en çok takip edilen haber sitesinin adaylarla ilgili haberleri nitel araştırma deseni seçilerek içerik çözümlemesi ile analiz edilmiştir. İçerik analizi sözlü ve yazılı metinler içinde yer alan belirli karakterlerden sistematik ve tarafsız sonuçlar çıkarmak için kullanılan bir araştırma tekniğidir (Stone ve ark. 1966 akt. Koçak ve Arun, 2006, s. 22). Analizde temel amaç araştırma soruları doğrultusunda metinlerin içerikleri hakkında sistematik veriler elde etmek ve bu verilerden hareketle yinelenen çıkarımlar yapmaktadır (Gökçe, 2003, s. 23). Bilimsel anlamda ölçmeye duyulan ihtiyaç, sayısal değerlerin analitik sınıflamalara uygulanmasını zorunlu kılmaktadır. Kümeleme ya da sayısallaştırma, içerik analizini tercih edilmesinde önemli bir etkendir, çünkü faktör analizi ve çok boyutlu ölçeklemenin aksine, analiz birimleri arasındaki sezgisel anlamlı benzerliklere dayanmaktadır ve sonuçta ortaya çıan dağılım, metnin çeşitli soyutlama düzeylerinin kavramsallaştırılmasını sağlamaktadır (Krippendorff, 2004, s. 221). Metin ile bağlam arasında az ya da çok ilişkinin var olduğu temel görüşten yola çıkarak (Gökçe, 2003, s. 25) metin içinde hangi noktaların göreli olarak vurgulandığı ya da ihmal edildiği belirlenmektedir.

\section{Örneklem}

Araştırmanın örneklemini 2018 Türkiye Cumhurbaşkanlığı seçiminde aday olan ve seçim sonuçlarında ilk dörde giren adayların seçim çalışmaları oluşturmaktadır. Seçim sonrası \%52,29 ile ilk sırayı alan Recep Tayyip Erdoğan, \%33,64 ile ikinci sırada yer alan Muharrem İnce, \%8,40 ile üçüncü sırada yer alan Selahattin Demirtaş ve \% 7,29 ile dördüncü sırada yer alan Meral Akşener'in (Seçim Sonuçları, 2018, www.internethaber.com) iletişim çalışmalarının incelenmesi amaçlanmıştır. Ancak Se- 
lahattin Demirtaş'ın siyasi kampanyasında yeterli iletişim çalışmasının olmaması nedeniyle örneklem dişı bırakılmıştır. Araştırma siyasal reklamlara adayların bireysel ve siyasal partilerinin resmi YouTube sayfasından ulaşılmıştır. Elde edilen her reklam videosu araştırmaya dâhil edilmiştir. Ancak parti imajı reklamları araştırma dışı bırakılmış yalnızca adayların Cumhurbaşkanlığı adaylığını kapsayan imaj ve konu reklamları incelenmiştir. Buna göre Erdoğan'ın 16, İnce'nin 16 ve Akşener'in 18 olmak üzere toplam 50 reklam filmi incelenmiştir. Adayların seçime yönelik sosyal medya paylaşımları kendi isimlerine açılan resmi Twitter hesaplarındaki seçime yönelik paylaşımlarından oluşmaktadır. Erdoğan'ın 238, İnce'nin 436 ve Akşener'in 743 olmak üzere toplam 1,417 Twitter mesajı incelenmiştir. Son olarak adayların seçim kampanyası boyunca yürüttükleri çalışmaların yer aldığı haberler Alexa internet sitesinden elde edilen verilere göre en çok takip edilen 10 internet sitesi içinde en çok ziyaret edilen ikinci haber sitesi Hürriyet gazetesinin internet sitesinden elde edilmiştir (Top Sites in Turkey, 2018, www.alexa.com). İlk sirada yer alan haber sitesi ensonhaber.com'un tek adayın haberlerine ağırlık verdiği belirlendiğinden örneklem dışı bırakılmıştır. Alexa, toolbarı araç çubuğuna yüklemiş kullanıcıların, son 3 ay içerisinde gerçekleştirdikleri internet sitesi trafiği değerlendirmesidir. Gerçekleşen bu trafik ziyaret ve sayfa görüntüleme olmak üzere 2 temel parametre ile hesaplanmaktadır. Ziyaret sayısı, gün içerisinde bir web siteye giriş yapan toplam Alexa kullanıcı sayısını vermektedir. Sayfa görüntüleme ise adından da anlaşılacağı gibi Alexa kullanıcıları tarafından görüntülenen toplam sayfa sayısını vermektedir. İnternet sitesinden yapılan arşiv taraması ile ulaşılan adayların seçim çalışmalarına yönelik tüm haberleri dikkate alındığında Erdoğan'ın 66, İnce'nin 60 ve Akşener'in 96 olmak üzere toplam 222 haberi incelenmiştir. Siyasal iletişim çalışmaları dikkate alındığında Akşener'in en çok Twitter mesajına sahip olduğu en çok Akşener'in seçime yönelik haberlerinin yer aldığı ve en çok siyasal reklamın Akşener'e ait olduğu görülmektedir (Tablo 1). Ancak reklam sürelerinin kategorilere dağılımı incelendiğinde en uzun reklam süresi $(\% 53,6)$ Erdoğan'a aittir. İnce ikinci sırada $(\% 26,1)$ ve Akşener üçüncü sırada (\%20,3) gelmektedir. Erdoğan'ın kampanya boyunca okuduğu şiir türü ile kurgulanan reklam filmleri dikkat çekmektedir. 
Tablo 1. Adayların Reklam, Twitter ve Haber Dağılımı

\begin{tabular}{llll}
\hline Aday & Reklam & Twitter & Haber \\
\hline Recep Tayyip Erdoğan & $\% 32$ & $\% 16,8$ & $\% 29,7$ \\
Muharrem İnce & $\% 32$ & $\% 30,7$ & $\% 27,0$ \\
Meral Akşener & $\% 36$ & $\% 52,5$ & $\% 43,3$ \\
Toplam & $\% 100$ & $\% 100$ & 100 \\
\hline
\end{tabular}

Çalışmanın sınırlılıkları arasında yalnızca üç partinin adaylarının siyasal reklamları, Twitter paylaşımları ve haberleri inceleme kapsamına alınması yer almaktadır. Ayrıca sadece siyasal reklam videoları incelenmiş televizyon programları, afiş, broşür, açıkhava reklamları gibi diğer tanıtım araçları çalışma dışı bırakılmıştır.

\section{Kodlama Kategorilerinin Oluşturulması}

Araştırmada adayların 2018 Cumhurbaşkanlığı adaylığı ile ilgili reklamlar, Twitter paylaşımları ve seçime yönelik çıkan haberler aynı kodlama aracıyla analiz edilmiştir. Siyasal reklam içerikleri ve gündem belirleme alanında yapılan çalışmalar doğru çözümleme aracının belirlenmesine 1ş1k tutmuştur (McCombs ve Shaw, 1972; Ghorpade,1986; Kaid ve Johnston 1991; Roberts ve McCombs, 1994; Lopez-Escobar vd., 1998; Min, 2003; Woodly, 2007; Sweetser vd., 2008; Vargo vd., 2014; Kim vd., 2016). Araştırmada özellikle Sweetser vd.(2008), Vargo vd.'nin (2014) ortaya koyduğu Kim ve arkadaşlarının geliştirdiği kodlama aracının uyarlanmış şekli kullanılmıştır. İlk başta özel olarak belirlenen gündem oluşturma konularının siyasal reklamlarda, adayların twittlerinde ve haber metinlerinde olup olmadığ gözden geçirilerek belirli konular seçilmiş ve kodlanmıştır. Devamında örneklemde var olduğu belirlenen kategoriler bırakılmış, olmayanlar ise uyarlanmış ya da eklenmiştir. Böylece "ekonomi, dış politika, bireysel özgürlükler, göç, eğitim, çevre, sosyal haklar" olmak üzere 7 kategori Kim ve arkadaşlarının ölçeğinden değiştirilmeden alınmış, hükümetin fonksiyonları iç politika olarak değiştirilmiş, özellikle reklamlarda çok sık kullanılan ve Sweetser vd.'nin (2008) ölçeğine dayanılarak oluşturulan milli değerler kategorisi de araştırmacılarca eklenmiştir. Kodlama kategorileri, örneklem olarak seçilen metinlerden kategorileri çıkarmak için daha önceden oluşturulan 
kelimeye dayalı listelerin uyarlanması ile oluşturulmuştur. Böylece kategorilerin frekansı kelimelerin geçiş sıklığının Nvivo yardımıyla ölçülmesi ile belirlenmiştir (Robberts ve McCombs, 1994, s.256; Vargo vd., 2014, s.10). Sonrasında bir kodlayıcı tarafından yazılım programının belirlediği kelimelerin bağlamsal olarak da uygunluğu incelenmiştir. Buna göre içerik analizinde kullanılan kategoriler ve alt kelime grupları şöyle gruplanmaktadır:

Bireysel özgürlükler: Din özgürlüğü, sosyal adalet, medeni hak, sivil haklar, ırk, kürtaj,bekâr kadın, bebek, doğum kontrolü, eşcinsel, LGBT, Kürt, ibadet,Alevi, Sünni, baskı² ${ }^{2}$ şiddet ${ }^{3}$, özgürlük, eşitlikçi, adil, inanç, kadın, başörtüsü, sağcl, solcu, Müslüman, Hiristiyan.

Çevre: Çevre ${ }^{4}$, ağaç, orman, yeşil/yeşilin, termal,elektrik,enerji, sürdürülebilir, tasarruf karbon, çevre kirliliği, temiz çevre, Akkuyu, nükleer, gaz, kömür, sera, kirlilik, emisyon, küresel 1sınma, iklim, fosil atık, Dünya Çevre Günü, bereketli topraklar, Nevruz.

Milli değerler: El ele, evlat, iman, Çanakkale, şehit,Atatürk,Mustafa Kemal, namaz, milli egemenlik, bayrak, milli birlik, beraberlik, beraberliği, cami, birlikte, güçlü, inşallah, Allah, kardeş, millet ${ }^{5}$, toprak, vatan ${ }^{6}$, hemşerilerim, hepimiz, tarihi, Anadolu, memleket, helal, bayram, Kur'an, ezan.

Ĕ̆itim: Öğrenci, üniversite, öğret, gençler, gençlere, eğitim, burs, akademi, kolej, harç, lise, ilkokul, ortaokul, Meslek Yüksek Okulu, okul, YÖK,LGS, ALES, Milli Eğitim.

Ekonomi: Ekonomi, vergi, işsizlik, istihdam, ticaret, sanayi, fakir, altyapı, yoksul, kredi, dolar, Euro, milyar, yerli, yoksul, yatırım, milli gelir, para7,

\footnotetext{
2"Baskın" kelimesi analiz dışı bırakılmıştır.

"Şiddetle" kelimesi analiz dışı bırakılmıştır.

4"Çevremdeki," çevreleri, çevresindeki analiz dışı bırakılmıştır.

5"Milletvekili" analiz dışı bırakılmıştır.

6"Vatandaş" analiz dışı bırakılmıştır.

7"Paramparça, paralel" gibi kelimeler analiz dışı bırakılmıştır.
} 
ücret, üretim, maaş, memur, faiz, fabrika, zengin, çiftçi, endüstri, Lira, mazot, borç, enflasyon, Merkez Bankası, Gayri Safi, GSYİH, iyileşme, düzelme, projeler, esnaf.

Göç: Arap, göç, mülteci, sınır, Ceylanpınar, Suriye, vize, vatandaşlık, pasaport, mavi kart, oturma izni, Afgan.

İç politika: Hükümet, FETÖ, hizmet, huzur, güvenle, güvenilir, güvenlik, güvenli, hukuk, parlamenter, PKK, demokratik, TRT, darbe, demokrasi, OHAL, değişim, rejim, asker/askerlik, Kandil, hükümetin rolü, büyük devlet, küçük hükümet, daha büyük hükümet, daha küçük hükümet, baskıcı yönetim, hedefimiz, teknoloji, bireysel silahsızlanma, hizlı tren, tehdit.

Dış politika: Terör, ABD, Amerika, Avrupa, Filistin, Katar, İran, Arap, Suriye, Rusya, Moskova, Trump, Merkel, Almanya, FETÖ, Arakan, Gazze, Kudüs, uluslararası, İsrail, nükleer silah, YPG, Kıbrıs, Ortadoğu, PYD, DEAŞ, Afrin, bomba, Esad, sınır, Uzakdoğu, küresel,birleşmiş milletler, dış politika, dış ilişkiler,diplomatik, diplomasi, denizaşırı, zirve toplantısı, körfez, Kafkaslar.

Sosyal haklar: Yardım ${ }^{8}$, sigorta, emektar, emekli, tıbbi, yaşlı, yoksul, çocuk, ebeveynlik, bekâr anne, doktor, büyükanne, doğum, kanser, sağlık, bağış, hasta, HIV, istismar.

\section{Güvenilirlik}

Araştırma için belirlenen kategorilerin Nvivo programında elde edilen sonuçların güvenirliliğini ölçmek için yapılan ön testte iki araştırmacı rastgele seçilen 10 haberde kategorilerin altında yer alan kelimeleri elle kodlayarak analiz etmiştir. Kategorilerde yer alan kelimelerin haber metninde yer alması var (1) ya da yok (0) olarak sayısallaştırılmış daha sonra her kategori için belirlenen kelimelerin var (1) sayısı toplanarak kategorinin frekansı toplam rakamla tespit edilmiştir. İlgili haberler aynı

\footnotetext{
8 "Yardımcı, yardımcılar,yardımcılık" analiz dışı bırakılmıştır.
} 
şekilde Nvivo'da kodlandıktan sonra Nvivo'daki sonuçlar ile kodlayıcıların sonuçları test edilmiştir. Aynı içeriğe ilişkin aynı kodlamayla tekrarlanan araştırmanın sonuçlarının aynı olması beklenmektedir diğer bir ifadeyle aynı fenomene, uygulama koşullarına bakılmaksızın, aynı şekilde cevap verildiğinde güvenilirlik sağlanmaktadır (Krippendorff, 2004, s. 211; Koçak ve Arun, 2006, s. 23). Güvenirlilik testi sonuçları Freelon (2013) tarafından geliştirilen "ReCal" online yazılım" ile gerçekleştirilmiştir. Kategorilere göre elde edilen Krippendorff's alpha güvenilirlik sonuçları şunlardır: ekonomi: ,891 (orijinal çalışmada ,933), dış politika: ,775(orijinal çalışmada ,734), bireysel özgürlük: ,906 (orijinal çalışmada ,911), göç: , 950 (orijinal çalışmada 1,000), iç politika: ,861(orijinal çalışmada 1,000), eğitim: ,912 (orijinal çalışmada 1,000), çevre: ,886(orijinal çalışmada 1,000), sosyal haklar: ,870 (orijinal çalışmada ,842), değerler: ,992. Kategorilerin çalışmada ölçek olarak kullanılması için gerekli güvenilirlik analizinde kodlayıcılar arasındaki uygunluğun/anlaşmanın \% 70'den daha yüksek, sınırının üzerinde, "mükemmel" düzeyde olduğu belirlenmiştir (Landis ve Koch, 1977, s.165; Tavşancıl-Aslan, 2001, s. 81).

\section{Veri Toplama}

Çalışma 2018 Cumhurbaşkanlığı seçimleri için hazırlanan seçim çalışmaları sürecini konu aldığından 1 Nisan ile 24 Haziran 2018 tarihleri arasında yapılmıştır. Araştırmada siyasal reklamlar elle kodlanmış ve kategorilerin kümelenmesi bu kategorilere harcanan süreye göre yapılmıştır. Siyasal reklam gündemini belirlemek için örneklemi oluşturan reklamlar içerik kategorilerine harcanan süre ile izlenme sıklığının çarpımı ile yayın genişliği elde edilmiştir (Roberts ve McCombs, 1994, s. 253). Böylece siyasal reklamlarda adayların ağırlık verdiği gündem konularının dağılımı elde edilmiştir. Yine 1 Nisan ile 24 Haziran tarihi aralığında Hürriyet haber portalında yer alan adayların seçim çalışmalarına yönelik haber metinleri ve adayların Twitter hesaplarındaki paylaşımları Nvivo yazılım programı desteği ile kelimelerin kullanım sıklığına göre kümelenmesi sağlanmıştır. İçerik kategorilerine göre dağılımdan elde edilen ver-

${ }^{9}$ Güvenilirlik analizi www.dfreelon.org/utils/recalfront/ sitesinden yapılmıştır 
iler SPSS yazılım programı ile analiz edilmiştir. Elde edilen veriler araştırmacılarca yorumlanmış çıkarımlar genellenmiştir. Araştırmanın bilimsel olabilmesi için analiz sonucu elde edilen bulguların ve yapılan çıkarımların genellenebilir olması gereklidir (Koçak ve Arun, 2006, s. 23). Böylece adayların gündem kategorileri sıralaması ve kullanılan mecraların birbiri ile benzerliği belirlenmiştir.

\section{Bulgular}

Yapılan içerik analizi ve reklam analizleri sonrasında elde edilen bulgular siyasal reklam gündemi, haber gündemi, adayların sosyal medyada Twitter hesaplarında paylaştıkları mesajlarından elde edilen bulgular ve tüm mesajların gündem kategorilerine dağılımının yer aldığı başlıklardan oluşmaktadır.

\section{Siyasal Reklam Gündemi}

Türkiye'de 2018 yılında yapılan Cumhurbaşkanlığı seçimlerine katılan ve ilk 4'e giren 3 partinin seçim kampanyası boyunca televizyon, YouTube, kendi sosyal medya hesaplarında paylaştıkları tüm siyasal reklamlara ulaşılmıştır. Reklamların süreler bazında saniye olarak kategorilere göre dağılımı yukarıda Tablo 1'de yer almaktadır. Şekil 3 'te de adayların siyasal reklamlarında temaların süre olarak dağılımı görülmektedir.

Şekil 3 incelendiğinde adayların siyasal reklamlarında temaların süre olarak dağılımı görülmektedir. Buna göre Erdoğan siyasal reklamlarında en fazla değerler kategorisinde yer alan alt kategorilere süre ayırmaktadır $(\% 45,2)$, ikinci sırada iç politika $(\% 18,4)$ gelmektedir. En az düzeyde ise dış politika $(\% 1,8)$ kategorisinde yer alan alt kategorilere süre ayırmaktadır. Göç kategorisine reklamlarda hiç yer verilmemekte, bireysel özgürlükler $(\% 3,7)$ ve çevre $(\% 3,7)$ kategorisi ise çok az yer almaktadır. İnce ise en fazla ekonomi (\%32,7) kategorisindeki konulara reklamlarında süre vermektedir. $\mathrm{O}$ da tıpkı Erdoğan gibi değerler kategorisine ikinci sırada (\%26) yer vermiş, göç kategorisine hiç yer vermemiştir. En az düzeyde ise dış politika $(\% 0)$ ve iç politika $(\% 4,6)$ kategorisindeki konulara yer vermektedir. 


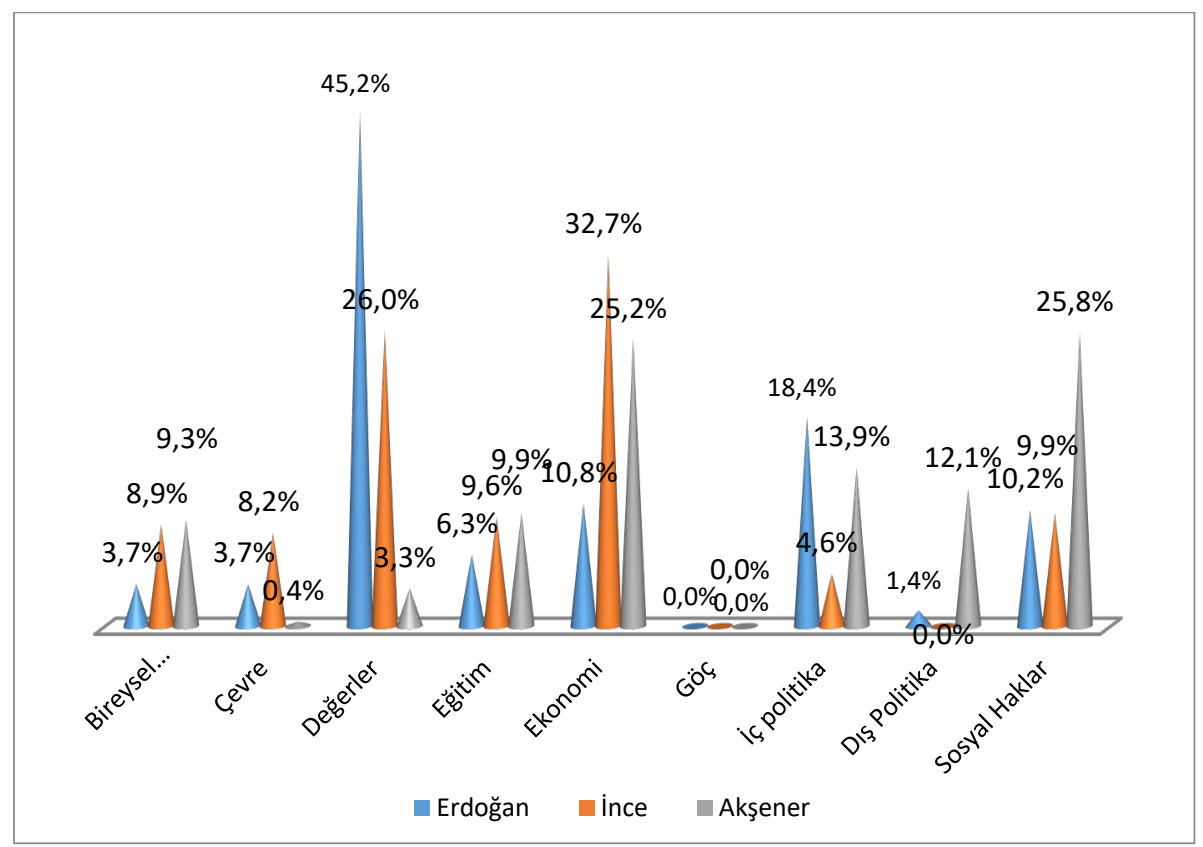

Şekil 3. Adayların Siyasal Reklamlarının Kategorilere Göre Dağılımı

Akşener'in siyasal reklamlarında kategorilere ayrılan süre bakımından en fazla oranda sosyal haklar $(\% 25,8)$ ve ekonomi $(\% 25,2)$ kategorisidir. Göç kategorisi Akşener'de de hiç yer almazken en az düzeyde ise çevre $(\% 0,4)$ ve değerler kategorisine $(\% 3,3)$ yer verildiği sonucu elde edilmiştir. Tüm adayların siyasal reklamlarının kategorilere dağılımı toplamında bireysel özgürlükler kategorisinde en fazla İnce'nin $(\% 37,7)$ yer aldı̆̆ı çevre kategorisinde yine İnce'nin (\%51,1), değerler kategorisinde Erdoğan'in $(\% 76,4)$, eğitim kategorisinde Erdoğan'ın $(\% 42,6)$, ekonomide İnce'nin $(\% 43,9)$, iç politikada Erdoğan'ın(\%71,1), dış politikada Akşener'in (\%72,4) ve sosyal haklarda Erdoğan'ın(\%41,1) yer aldığı sonucu elde edilmiştir (Şekil 4). 


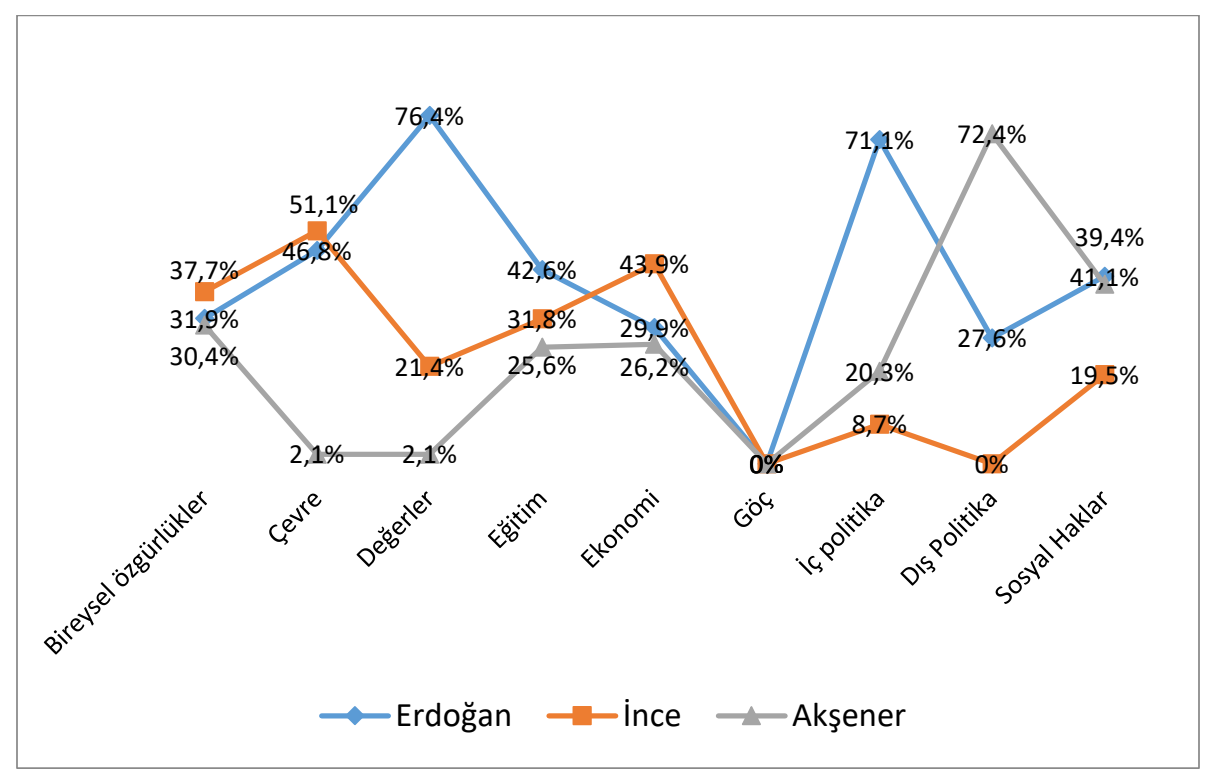

Şekil 4. Adayların Kategorilere Göre Dă̆ılımı

\section{Twitter Gündemi}

Adayların Twitter resmi hesaplarındaki toplam 1,417 twitt incelenmiştir ölçekte yer alan kategorilere göre dağılımları alt kategorilerde yer alan kelimeler düzeyinde analiz edilmiştir. Buna göre Erdoğan, İnce ve Akşener'in sosyal medya hesaplarındaki paylaşımlarından seçim kampanyası boyunca hangi gündem konularını öne çıkardıkları tespit edilmiştir (Şekil 5).

Şekil 5 incelendiğinde adayların sosyal medya hesapları Twitter paylaşımlarının kategorilere göre dağılımı görülmektedir. Buna göre Erdoğan'ın paylaşımlarında en fazla değerler kategorisinin $(\% 33,4)$ yer aldığı görülmektedir. İkinci sırada ise ekonomi $(\% 23,1)$ gelmektedir ve en az düzeyde ise göç $(\% 0,7)$ bireysel özgürlükler $(\% 3,4)$ kategorisi olduğu sonucuna ulaşılmıştır. İnce ise en fazla değerler $(\% 28,7)$ kategorisindeki konulara twittlerinde yer vermektedir. İkinci sırada eğitim gelmektedir $(\% 26,85)$. O da tıpkı Erdoğan gibi göç kategorisine çok az yer vermiştir 
$(\% 0,6)$. Yine çevre $(\% 1,5)$ ve bireysel özgürlükler $(\% 3,7)$ kategorisindeki konulara çok az yer vermektedir.

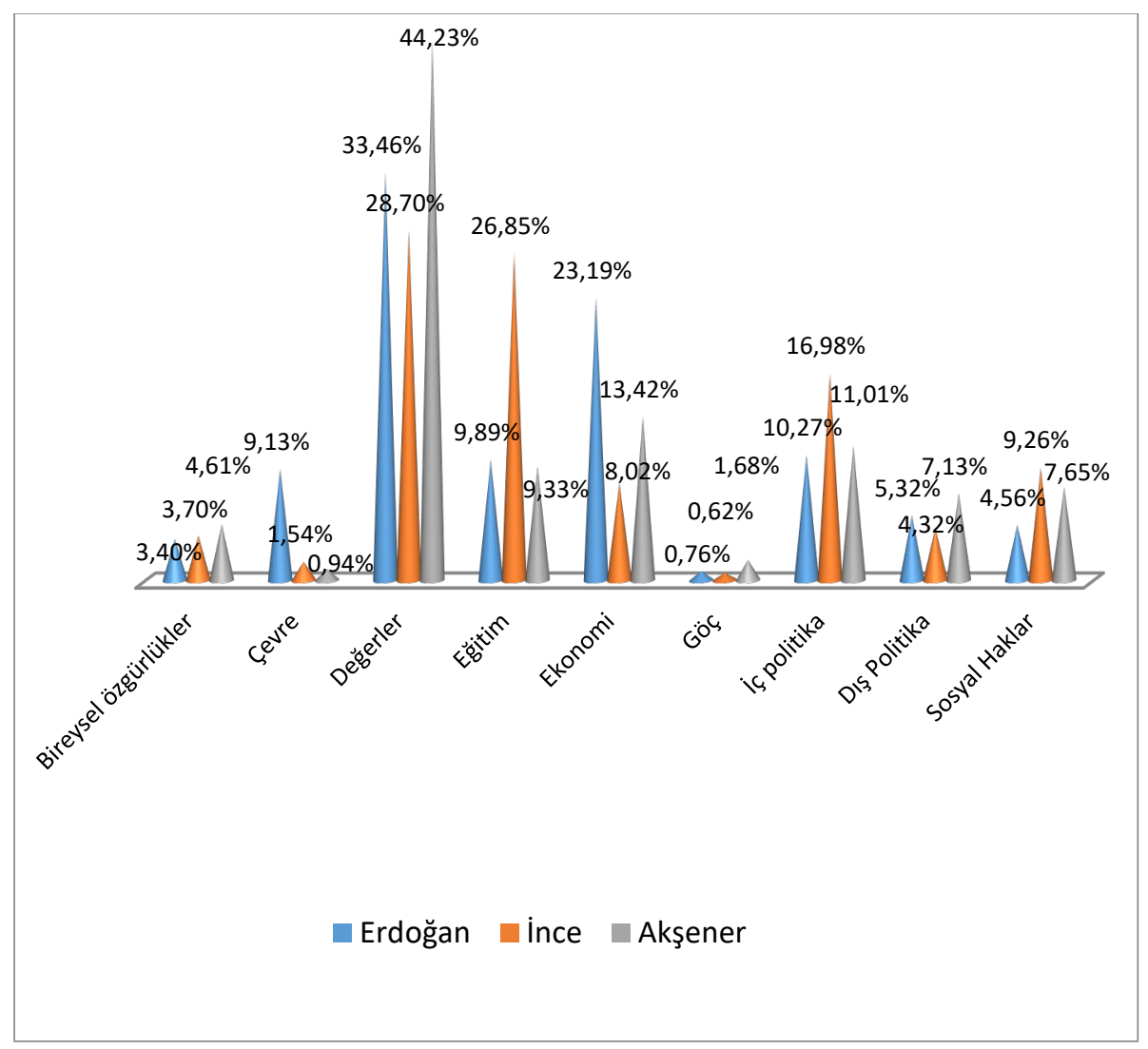

Şekil 5. Adayların Twitter Paylaşımlarının Kategorilere Göre Dağılımı

Akşener'in Twitter paylaşımları incelendiğinde en fazla oranda değerler $(\% 44,2)$ ve ekonomi $(\% 13,4)$ kategorisidir. Çevre kategorisi $(\% 0,9)$ ve göç kategorisine $(\% 1,6)$ Akşener'in Twitter hesaplarında çok az yer verilmişitir. Tüm adayların Twitter paylaşımlarının kategorilere dağılımı toplamına bakıldığında bireysel özgürlükler kategorisinde en fazla Akşener'in $(\% 67,6)$ yer aldığı çevre kategorisinde Erdoğan'ın $(\% 63,1)$, değerler kategorisinde $(\% 69,9)$, eğitim $(\% 44,6)$, ekonomide $(\% 59,5)$, göç $(\% 80)$, iç politikada $(\% 56,5)$, dış politikada $(\% 70,8)$ ve sosyal haklarda $(\% 63,4)$ Akşener'in ilk sırada yer aldığı sonucu elde edilmiştir (Şekil 6). 


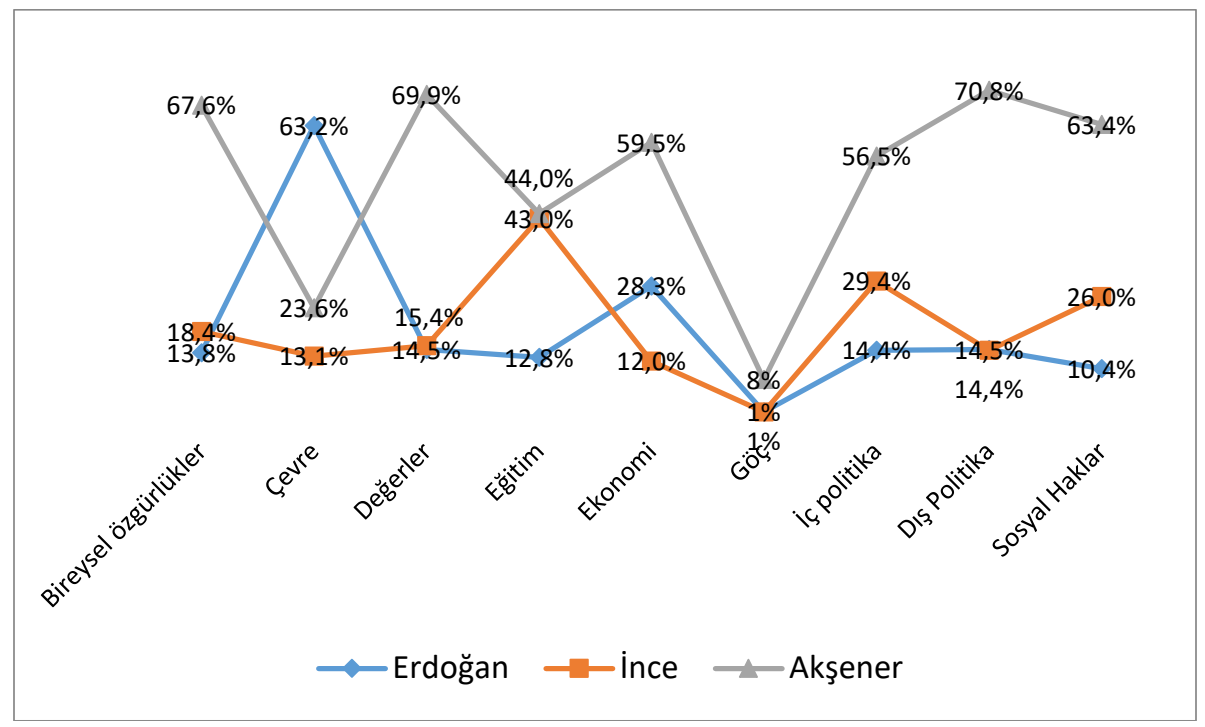

Şekil 6. Twitter Paylaşımlarının Adaylara Göre Dă̆ılımı

Çalışmada adayların siyasal reklam konuları ile Twitter paylaşımlarındaki gündem konuları arasında benzerlik araştırma sorusu için (AS1) adayların reklam ve Twitter paylaşımlarının kategorik dağılımlarının frekans hesaplama sonucu incelenmiş ve adaylardan Recep Tayyip Erdoğan'ın siyasal reklamlarda ve Twitter paylaşımlarında da değerler kategorinin (1) ilk sırada olduğu belirlenmiştir. İç politika kategorisinin reklamlarda (2) Twitter paylaşımlarında (3) ve ekonomi kategorisinin reklamlarda (3) Twitter paylaşımlarında (2) çok yakın sıralamada yer alırken, her ikisinde de göç kategorisinin en sonunda (9) yer aldığ1 görülmektedir. İnce'nin reklam ve Twitter paylaşımlarındaki konu dağılımında ilk sırada siyasal reklamlarda ekonomi ve Twitter'da değerler kategorisi gelmektedir. İnce'nin göç kategorisi her iki sıralamada da en sonda $(8,9)$ yer almaktadır. Akşener'in konu dağılımı incelendiğinde siyasal reklamlarda sosyal haklar (1) ve Twitter'da değerler (1) kategorinin yer aldığı, ekonomi kategorisinin her iki sıralamada da aynı(2) olduğu sonucu elde edilmiştir. Aynı şekilde iç politika(3) her iki sıralamada da aynı sırada yer almaktadır. Eğitim kategorisi siyasal reklamlarda (5) ve Twitter 
paylaşımlarında (4) çok yakın sıralardadır, göç ve çevre kategorisi için de aynı sonuç elde edilmiştir. Genel itibarıyla göç tüm adayların siyasal reklamlar ve Twitter paylaşımlarında son sırada yer almaktadır (Tablo 2).

Tablo 2. Siyasal Reklamlar ve Twitter Paylaşımlarındaki Gündem Konularının Karşılaştırması

\begin{tabular}{|c|c|c|c|c|c|c|}
\hline SIRASI & ERDOĞA & & INCE & & AKŞENER & \\
\hline & Reklam & Twitter & Reklam & Twitter & Reklam & Twitter \\
\hline 1 & değerler & değerler & ekonomi & değerler & sosyal haklar & değerler \\
\hline 2 & $\begin{array}{l}\text { iç poli- } \\
\text { tika }\end{array}$ & ekonomi & değerler & eğitim & ekonomi & ekonomi \\
\hline 3 & ekonomi & iç politika & $\begin{array}{l}\text { sosyal } \\
\text { haklar }\end{array}$ & $\begin{array}{l}\text { iç poli- } \\
\text { tika }\end{array}$ & iç politika & iç politika \\
\hline 4 & $\begin{array}{l}\text { sosyal } \\
\text { haklar }\end{array}$ & eğitim & eğitim & $\begin{array}{l}\text { sosyal } \\
\text { haklar }\end{array}$ & dış politika & eğitim \\
\hline 5 & eğitim & çevre & $\begin{array}{l}\text { bireysel } \\
\text { özgürlükler }\end{array}$ & ekonomi & eğitim & $\begin{array}{l}\text { sosyal } \\
\text { haklar }\end{array}$ \\
\hline 6 & $\begin{array}{l}\text { çevre, } \\
\text { bireysel } \\
\text { özgürlük } \\
\text { ler }\end{array}$ & diş politika & çevre & $\begin{array}{l}\text { diş poli- } \\
\text { tika }\end{array}$ & $\begin{array}{l}\text { bireysel } \\
\text { özgürlükler }\end{array}$ & dış politika \\
\hline 7 & $\begin{array}{l}\text { diş poli- } \\
\text { tika }\end{array}$ & $\begin{array}{l}\text { sosyal } \\
\text { haklar }\end{array}$ & iç politika & $\begin{array}{l}\text { bireysel } \\
\text { özgürlükl } \\
\text { er }\end{array}$ & değerler & $\begin{array}{l}\text { bireysel } \\
\text { özgürlük }\end{array}$ \\
\hline 8 & göç & $\begin{array}{l}\text { bireysel } \\
\text { özgürlükler }\end{array}$ & $\begin{array}{l}\text { göç-dış poli- } \\
\text { tika }\end{array}$ & çevre & çevre & göç \\
\hline 9 & & göç & & göç & göç & çevre \\
\hline
\end{tabular}

Çalışmada reklam gündeminde Erdoğan ve Akşener'in eğitim ve bireysel özgürlükler kategorisinin benzer sıralamada, Twitter paylaşımları incelendiğinde değerler, ekonomi, iç politika, dış politika ve eğitim kategorisinde benzer sıralamada olduğu elde edilmektedir. Göç konusu her iki aday için son sırada gelmektedir. Yine her adayın Twitter paylaşımları içinde ilk sırayı değerler, üçünü sırayı iç politika ve altıncı sırayı dış politika kategorisinin aldığı görülmektedir. Böylece Twitter paylaşımları incelendiğinde Erdoğan ve Akşener'in birçok kategorinin sıralamasında benzerlik taşıdığı görülmektedir. 


\section{Haber Gündemi}

Maliyeti yüksek reklamların yanında haber sitelerinde birçok kişiye ulaşan haberler siyasal kampanyalarda adaylara avantaj kazandırmaktadır. Adaylar her gittikleri mitingin haber değeri taşıması için ilginç taktikler kullanarak miting alanına gelen hedef kitlenin ve medyanın dikkati çekilmeye çalışılmaktadır. Adayların seçim çalışmalarına yönelik olarak Erdoğan'ın 66, İnce'nin 60 ve Akşener'in 96 olmak üzere toplam 222 haber incelenmiştir. Çalışmada adayların seçim çalışmalarına yönelik haberlerin kategorilerde yer alan kelime düzeyinde dağılımı Şekil 7'de yer almaktadır.

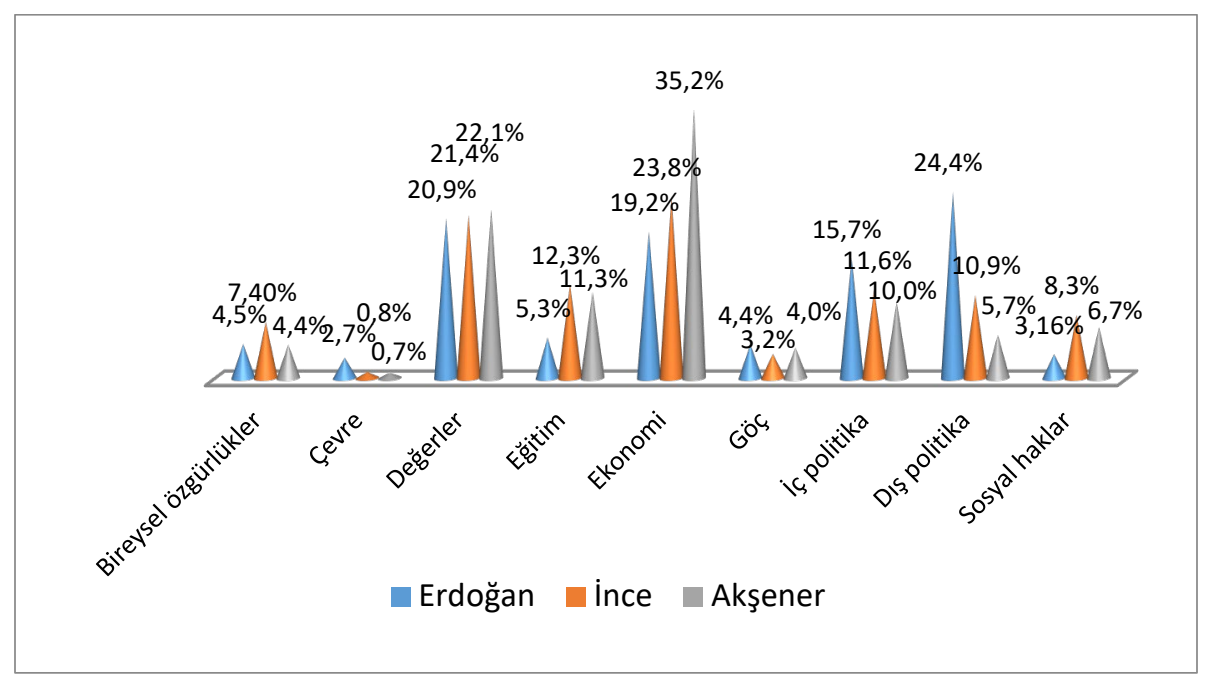

Şekil 7. Adaylar Hakkında Çıkan Seçim Haberlerinin Kategorilere Göre Dağılımı

Şekil 7 incelendiğinde Erdoğan ile ilgili sıralamada ilk sırada dış politika kategorisi $(\% 24,4)$ olurken ikinci sırada ise değerler $(\% 20,9)$ kategorsinin yer aldığ 1 görülmektedir. En az haber ise çevre $(\% 2,7)$ ve sosyal haklar kategorisindedir. İnce ile ilgili haberler incelendiğinde en fazla ekonomi kategorisinde $(\% 23,8)$ olduğu görülmektedir. İkinci sırada ise değerler kategorisinde $(\% 21,4)$ en az düzeyde ise çevre $(\% 0,7)$ ve göç kategorisinde $(\% 3,2)$ olarak yer almaktadır. Akşener haberleri incelendiğinde 
en çok ekonomi $(\% 35,2)$ ve değerler $(\% 22,1)$ kategorisinde olduğu görülmektedir. En düşük haber konusu çevre $(\% 0,8)$ ve diş politika $(\% 5,7)$ olarak görülmektedir. Tüm adaylar hakkında yer alan siyasal haberlerinin kategorilere dağılımı toplamına bakıldığında bireysel özgürlükler kategorisinde en fazla İnce'nin $(\% 40,5)$ yer aldığ çevre kategorisinde Erdoğan'ın $(\% 69,8)$, değerler kategorisinde Erdoğan'ın (\%38,6), eğitim kategorisinde $(\% 41,4)$ İnce'nin, ekonomide $(\% 46,1)$ Akşener'in, göçte $(\% 34,2)$ Erdoğan'ın, iç politikada $(\% 48,4)$ İnce'nin, dış politikada İnce'nin $(\% 66,2)$ olduğu ve sosyal haklarda Akşener $(\% 39,1)$ ve ince'nin $(\% 39,5)$ eşit dağılıma sahip olduğu sonucu elde edilmiştir (Şekil 8).

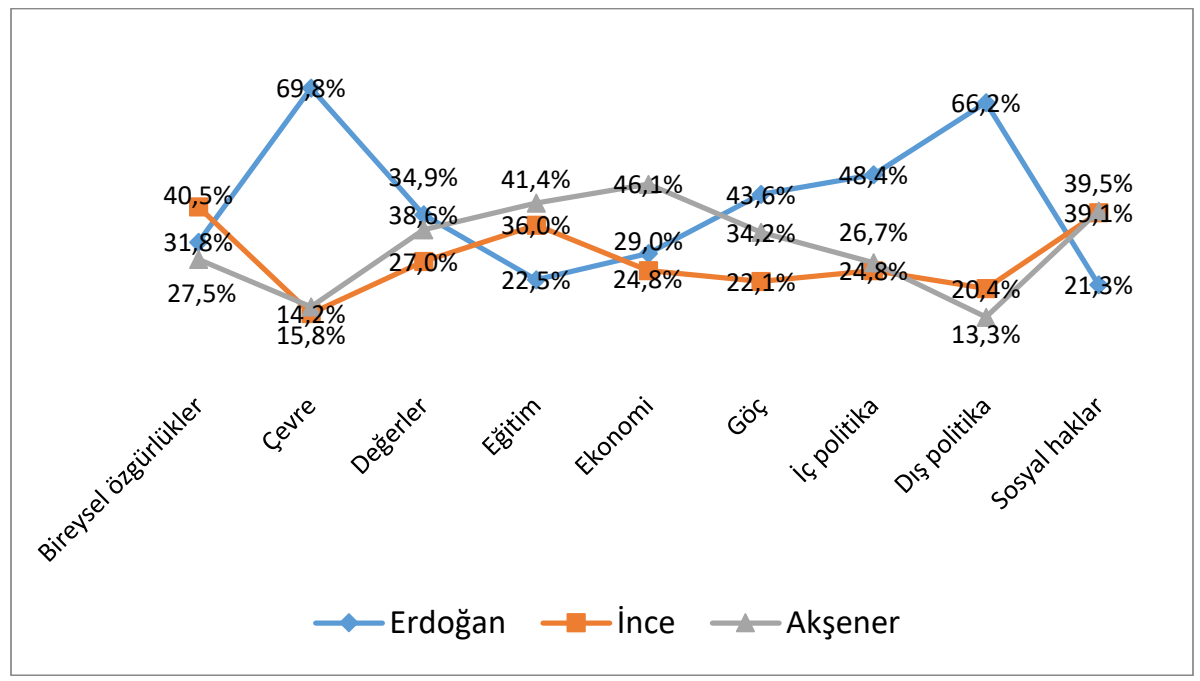

Şekil 8. Haber Kategorisinin Adaylara Göre Dağılımı

Çalışmada diğer araştırma sorusu için (AS2) adayların siyasal reklamlarında yer alan konu dağılımı ile yer aldıkları siyasal haberlerdeki gündem konuları kategorik dağılımlarının frekans dağılımları sonucu incelenmiş arasında benzerlik ortaya konmaya çalışılmıştır. Recep Tayyip Erdoğan'ın siyasal reklamlarda en çok değerler kategorinin yer aldığı (1) ancak haberlerde daha çok diş politika kategorinin (1) ilk sırada olduğu belirlenmiştir. İç politika kategorisi reklamlarda (2) haber içeriklerinde değerler ikinci sıradadır. Erdoğan'ın hem reklamlardaki hem de haberlerdeki kategori dağılımında ekonomi aynı sıralamada (3) yer almaktadır. 
Eğitim kategorisinin reklam ve haber gündeminde aynı sıralamada yer aldığı (5), bireysel özgürlükler kategorisinin de aynı sırada olduğu (6) görülmektedir. İnce'nin reklam ve haber içeriklerindeki konu dağılımında ilk sirada siyasal reklamlarda ve haber kategorisinde ekonomi(1) yer almaktadır ve yine siyasal haberler ve reklamlarda değerler kategorisi aynı sıralamada (2) yer almaktadır. Göç kategorisi hem reklamlarda hem de haberlerde en son siralarda yer almaktadır. Akşener'in konu dağılımı incelendiğinde siyasal reklamlarda sosyal haklar (1) ve haberlerde ekonomi (1) kategorinin yer aldığ 1 sonucu elde edilmiştir. Ancak siyasal reklamlar ve haberde kategoriler arasında benzer sıralamaya rastlanmamıştır (Tablo 3).

Tablo 3. Siyasal Reklamlar ve Haberlerin Gündem Konularının Karşılaştırması

\begin{tabular}{|c|c|c|c|c|c|c|}
\hline SIRASI & ERDOĞAN & & İNCE & & AKŞENER & \\
\hline & Reklam & Haber & Reklam & Haber & Reklam & Haber \\
\hline 1 & değerler & dış politika & ekonomi & ekonomi & $\begin{array}{l}\text { sosyal } \\
\text { haklar }\end{array}$ & ekonomi \\
\hline 2 & iç politika & değerler & değerler & değerler & ekonomi & değerler \\
\hline 3 & ekonomi & ekonomi & $\begin{array}{l}\text { sosyal } \\
\text { haklar }\end{array}$ & eğitim & iç politika & eğitim \\
\hline 4 & $\begin{array}{l}\text { sosyal } \\
\text { haklar }\end{array}$ & iç politika & eğitim & iç politika & dış politika & iç politika \\
\hline 5 & eğitim & eğitim & $\begin{array}{l}\text { bireysel } \\
\text { özgürlükler }\end{array}$ & dış politika & eğitim & $\begin{array}{l}\text { sosyal } \\
\text { haklar }\end{array}$ \\
\hline 6 & $\begin{array}{l}\text { çevre, bi- } \\
\text { reysel } \\
\text { özgürlükler }\end{array}$ & $\begin{array}{l}\text { bireysel } \\
\text { özgürlükler }\end{array}$ & çevre & $\begin{array}{l}\text { sosyal } \\
\text { haklar }\end{array}$ & $\begin{array}{l}\text { bireysel } \\
\text { özgürlükler }\end{array}$ & dış politika \\
\hline 7 & dış politika & göç & iç politika & $\begin{array}{l}\text { bireysel } \\
\text { özgürlükler }\end{array}$ & değerler & $\begin{array}{l}\text { bireysel } \\
\text { özgürlükler }\end{array}$ \\
\hline 8 & göç & $\begin{array}{l}\text { sosyal } \\
\text { haklar }\end{array}$ & $\begin{array}{l}\text { göç-dış } \\
\text { politika }\end{array}$ & göç & çevre & göç \\
\hline 9 & & çevre & & çevre & göç & çevre \\
\hline
\end{tabular}

Ayrıca Tablo 3'te görüldüğü gibi Erdoğan, İnce ve Akşener'in haber kategorisinde değerler, çevre ve iç politika konularının, yine İnce ve Akşener'in değerler, bireysel özgürlükler, ekonomi, eğitim, göç ve çevre kategorisinin benzer sıralamada yer aldığ tespit edilmiştir.

Çalışmada adayların Twitter paylaşımları, haber sitesinde yayınlanan haberlerinde yer alan gündem konuları arasında benzerlik olup olmadığına yönelik araştırma sorusuna (AS3) cevap aramak amacıyla adayların Twitter paylaşımlarının ve haber içeriklerinin kategorik 
dağglımlarının frekans sonucu incelenmiştir. Buna göre Erdoğan'ın haber ve Twitter gündem kategorileri arasında benzerlik bulunmadığı sonucuna varılmıştır. İnce'nin ise yalnızca bireysel özgürlükler(7) aynı sırada yer almakta haber içeriklerinde göç(8) ile Twitter paylaşımlarındaki göç(9) ve haber içerilerindeki çevre(9) ile Twitter paylaşımlarındaki çevre(8) kategorisinin sıralaması benzerlik göstermektedir. Akşener'in siyasal kampanya gündeminde Twitter ve haber içeriklerinde ilk iki sırada değerler (Twitter'da 1, haberde 2) ve ekonomi (Twitter'da 2, haberde 1) kategorisi yine iç politika (Twitter'da 3 haberde 4) ve eğitim (Twitter'da 4 haberde 3 ) kategorisi yakın sıralamada yer almaktadır. Sosyal haklar (5) dış politika(6), bireysel özgürlükler(7), göç(8) ve çevre(9) kategorileri ise haber ve Twitter paylaşımlarında aynı sıralamada yer almaktadır (Tablo 4).

Tablo 4. Twitter ve Haberlerin Gündem Konularının Karşılaştırması

\begin{tabular}{|c|c|c|c|c|c|c|}
\hline SIRASI & ERDOĞA & & İNCE & & AKŞENER & \\
\hline & Twitter & Haber & Twitter & Haber & Twitter & Haber \\
\hline 1 & değerler & dış politika & değerler & ekonomi & değerler & ekonomi \\
\hline 2 & ekonomi & değerler & eğitim & değerler & ekonomi & değerler \\
\hline 3 & iç politika & ekonomi & iç politika & eğitim & iç politika & eğitim \\
\hline 4 & eğitim & iç politika & $\begin{array}{l}\text { sosyal } \\
\text { haklar }\end{array}$ & iç politika & eğitim & iç politika \\
\hline 5 & çevre & eğitim & ekonomi & dış politika & $\begin{array}{l}\text { sosyal } \\
\text { haklar }\end{array}$ & $\begin{array}{l}\text { sosyal } \\
\text { haklar }\end{array}$ \\
\hline 6 & dış politika & $\begin{array}{l}\text { bireysel } \\
\text { özgürlükler }\end{array}$ & dış politika & $\begin{array}{l}\text { sosyal } \\
\text { haklar }\end{array}$ & $\begin{array}{l}\text { dış poli- } \\
\text { tika }\end{array}$ & dış politika \\
\hline 7 & $\begin{array}{l}\text { sosyal } \\
\text { haklar }\end{array}$ & göç & $\begin{array}{l}\text { bireysel } \\
\text { özgürlükler }\end{array}$ & $\begin{array}{l}\text { bireysel } \\
\text { özgürlükler }\end{array}$ & $\begin{array}{l}\text { bireysel } \\
\text { özgürlük }\end{array}$ & $\begin{array}{l}\text { bireysel } \\
\text { özgürlükler }\end{array}$ \\
\hline 8 & $\begin{array}{l}\text { bireysel } \\
\text { özgürlükler }\end{array}$ & sosyal haklar & çevre & göç & göç & göç \\
\hline 9 & göç & çevre & göç & çevre & çevre & çevre \\
\hline
\end{tabular}

\section{Gündem Kategorileri Toplamının Adaylara Göre Dağılımı}

Çalışmada seçime katılan adayların siyasal reklam, Twitter paylaşımları ve haber içeriklerinin içerik kategorilerinin dağılımı incelendiğinde Erdoğan'in toplam 4724, İnce'nin 3167 ve Akşener'in 4232 kategorik verisi incelenmiş Şekil 8'deki sonuçlar elde edilmiştir. Buna göre adaylardan Erdoğan'ın genel dağılımında ilk sırada değerler (\%27,8), ikinci sırada dış politika $(\% 17,6)$, üçüncü sırada ekonomi $(\% 17,3)$, dördüncü sırada iç politika $(\% 16,1)$, beşinci sırada eğitim $(\% 5,8)$, altıncı sırada sosyal haklar 
$(\% 5,0)$, yedinci sırada bireysel özgürlükler $(\% 3,9)$, sekizinci sırada çevre $(\% 3,3)$ ve son olarak göç $(\% 3,1)$ gelmektedir (Şekil 8$)$. İnce'nin kategori dağ 1 lımında ise ilk sırada ekonomi $(\% 23,8)$, ikinci sırada $(\% 23,0)$ değerler, üçüncü sırada eğitim $(\% 13,3)$, dördüncü sırada iç politika $(\% 10,9)$, beşinci sırada sosyal haklar $(\% 8,8)$, altıncı sırada diş politika $(\% 8,2)$, yedinci sırada bireysel özgürlükler $(\% 7,3)$, sekizinci sırada göç $(\% 2,4)$ ve son olarak çevre $(\% 2,2)$ konusu gelmektedir (Şekil 8). Akşener'in gündem konusu dağlımı incelendiğinde ilk sırada ekonomi (\%29,3), ikinci sırada değerler $(\% 25,1)$, üçüncü sırada eğitim $(\% 10,7)$, dördüncü sırada iç politika $(\% 10,6)$, beşinci sırada sosyal haklar $(\% 9,0)$, altıncı sırada dış politika $(\% 6,7)$, yedinci sırada bireysel özgürlükler $(\% 4,7)$, sekizinci sırada göç $(\% 3,1)$ ve son olarak çevre $(\% 0,7)$ gelmektedir (Şekil 9).

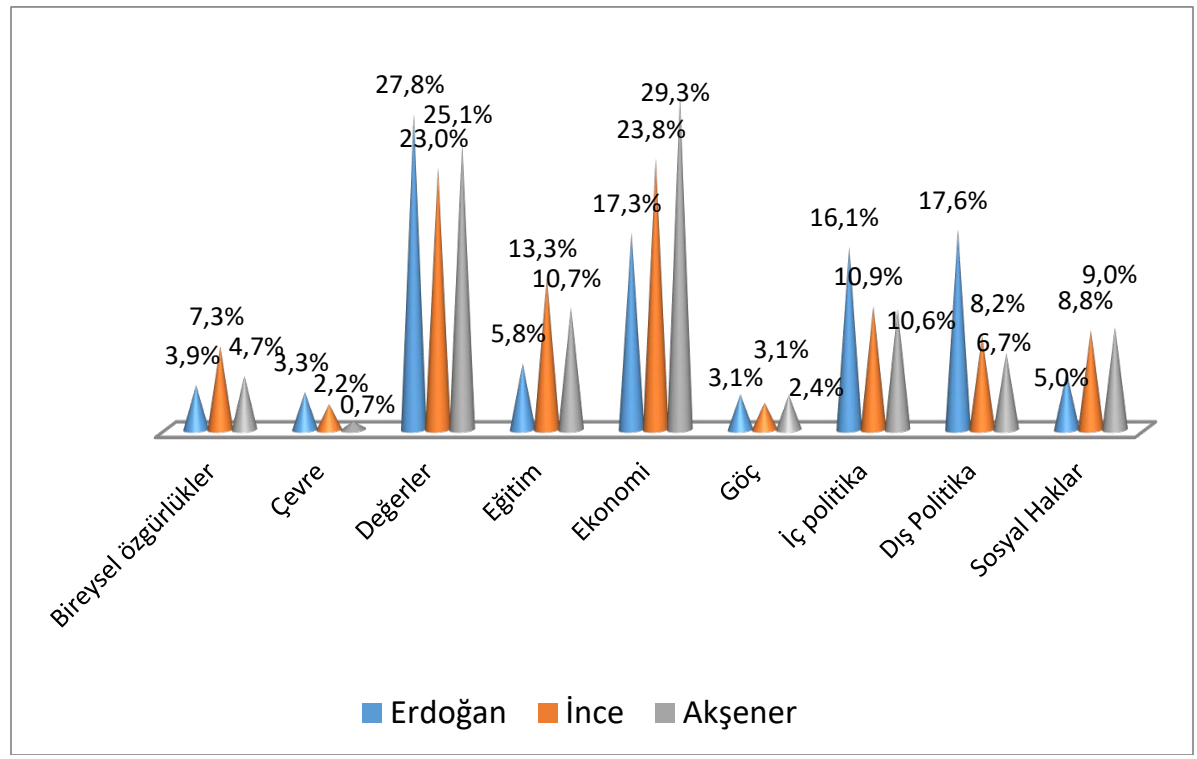

Şekil 9. Siyasal Reklam, Twitter ve Haberlerin Gündem Konularn Toplamının Adaylara Göre Dağılımı

Her adayın konu dağılımında bireysel özgürlüklerde İnce, çevre ve değerler kategorisinde Erdoğan'ın, eğitimde İnce'nin, ekonomide Akşener'in, göçte Erdoğan'ın ve İnce'nin, iç politikada Erdoğan'ın ve sosyal haklarda Akşener'in kategori dağılımında ilk sırada yer aldığ görülmektedir (Şekil 9). 
Tablo 5. Siyasal Reklam, Twitter ve Haberlerin Gündem Konular Toplamının Karşılaştırması

\begin{tabular}{llll}
\hline SIRASI & ERDOĞAN & INCE & AKŞENER \\
\hline $\mathbf{1}$ & Kategori & Kategori & Kategori \\
$\mathbf{2}$ & değerler & ekonomi & ekonomi \\
$\mathbf{3}$ & diş politika & değerler & değerler \\
$\mathbf{4}$ & ekonomi & eğitim & eğitim \\
$\mathbf{5}$ & iç politika & iç politika & iç politika \\
$\mathbf{6}$ & eğitim & sosyal haklar & sosyal haklar \\
$\mathbf{7}$ & sosyal haklar & diş politika & diş politika \\
$\mathbf{8}$ & bireysel özgürlükler & bireysel özgürlükler & bireysel özgürlükler \\
$\mathbf{9}$ & çevre & çevre & göç \\
\hline & göç & göç & çevre \\
\hline
\end{tabular}

Araştırma sorularından "Adaylar arasında siyasal reklamlar, Twitter paylaşımları, haber sitesinde yayınlanan haber içerikleri toplamında gündem konuları arasında benzerlik var midır?" sorusuna (AS4) cevap aramak amaciyla siyasal kampanya boyunca siyasal reklamlar, Twitter paylaşımları ve yayınlanan haber içeriklerinin kategorik dağılımı karşılaştırılmıştır. Tablo 5 incelendiğinde Erdoğan ile İnce ve Akşener arasında iç politika kategorisinin sırası ile bireysel özgürlükler sırasının benzerlik taşıdığı sonucu elde edilmiştir. İnce ile Akşener arasında da ekonomi, değerler, eğitim, iç politika, sosyal haklar, dış politika ve bireysel özgürlükler sıralamasının benzerlik taşıdığı sonucu elde edilmiştir.

Son olarak çalışmada adayların kategorilerinin tüm sayısal değerleri toplamında $(\mathrm{N}=11,623)$ konu dağılımı analiz edilmiş ve bireysel özgürlüklerde İnce'nin (\%31,1) ilk sırada Akşener'in ikinci sırada (\% 30,2) ve Erdoğan'ın üçüncü sırada $(\% 27,9)$ olduğu sonucu elde edilmiştir. Yine çevre kategorisinde Erdoğan'ın ilk sırada $(\% 43,2)$, İnce'nin ikinci sırada $(\% 19,6)$ ve Akşener üçüncü sırada $(\% 8,5)$ olduğu, değerler kategorisinde ise yine Erdoğan'ın ilk sırada $(\% 37,2)$, Akşener'in ikinci sırada $(\% 30,1)$ ve İnce'nin üçüncü sırada $(\% 20,6)$ olduğu ve eğitim kategorisinde Akşener'in ilk sırada $(\% 36,6)$, İnce'nin ikinci sırada (\%34,0), Erdoğan'ın üçüncü sırada $(\% 22,1)$ olduğu tespit edilmiştir. Ekonomi kategorisinde de Akşener'in ilk sırada $(\% 42,1)$, Erdoğan'ın ikinci sırada $(\% 27,8)$, İnce'nin üçüncü sırada $(\% 25,6)$ olduğu, göç kategorisinde Erdoğan'ın ilk sırada $(\% 39,8)$, Akşener'in ikinci sırada $(\% 35,2)$ ve İnce'nin üçüncü sırada $(\% 20,4)$ olduğu görülmüştür. İç politikada Erdoğan'in ilk sırada (\%45,7), Akşener'in ikinci 
sırada $(\% 27,1)$ ve İnce'nin üçüncü sırada $(\% 20,7)$ olduğu, Erdoğan'ın ilk sırada $(\% 57,6)$, Akşener'in ikinci sirada $(\% 19,63)$ ve İnce'nin üçüncü sırada (\%18,) olduğu ve sosyal haklar kategorisinde de Akşener'in ilk sırada $(\% 39,3)$, İnce'nin ikinci sırada olduğu $(\% 28,6)$ ve Erdoğan'ın üçüncü sırada olduğu $(\% 24,4)$ tespit edilmiştir.

\section{Sonuç}

Araştırmada 2018 Türkiye Cumhurbaşkanlığı seçiminde aday olan ve seçim sonuçlarında ilk dörde giren ancak üç adayın seçim çalışmaları incelenmiştir. Çalışma kapsamında Erdoğan'ın 16, İnce'nin 16 ve Akşener'in 18 olmak üzere toplam 50 reklam filmi ile Erdoğan'in 238, İnce'nin 436 ve Akşener'in 743 olmak üzere toplam 1,417 Twitter incelenmiştir. Son olarak adayların seçim kampanyası boyunca yürüttükleri çalışmaların yer aldığı haberler Alexa internet sitesinden elde edilen verilere göre en çok takip edilen haber sitesi arasında yer alan Hürriyet gazetesinin internet sitesinden elde edilmiştir. Adayların seçim çalışmalarına yönelik Erdoğan'ın 66, İnce'nin 60 ve Akşener'in 96 olmak üzere toplam 222 haberi incelemeye dâhil edilmiştir. Ancak Çalışmanın son aşamasında Erdoğan'in 4,224 İnce'nin 3,167 ve Akşener'in 4,232 kategorik verisi değerlendirmeye $(\mathrm{N}=11,623)$ alınmıştır. Erdoğan ve İnce'nin Cumhurbaşkanlığı seçimlerinde twitt paylaşımlarının sayısı azken siyasal reklamlarının (Çoğunluğu şiirden oluşan ortalama $2 \mathrm{dk}$ ) ve haber metinlerinin uzun olduğu dikkat çekmektedir. Kategori dağılımda en uzun reklam süresi $(\% 53,6)$ Erdoğan'a aittir. İnce ikinci sırada $(\% 26,1)$ ve Akşener üçüncü sırada $(\% 20,3)$ gelmektedir.

Adaylar seçmenleri ikna etmede etkili bir araç olan reklamlarda duygusal mesajlara yer vererek tutum değişimini amaçlamaktadır (Sutherland ve Galloway, 1981). Erdoğan'ın reklam videolarında en çok Türk bayrağı, cami, Çanakkale, Atatürk gibi göstergelerle milli birlik, beraberlik vurgusu yapılmaktadır. Daha sonra sırasıyla 15 Temmuz Darbe Girişimi ile iç politikaya, ekonomiye, çocuklar, kadınlar ve yaşlıların yer aldığı görüntülerle sosyal haklara vurgu yapılmaktadır. İnce'nin reklamlarında esnaf, çiftçi, sanayi görüntüleri ile ekonomi kategorisine ait mesajlar öne çıkmaktadır, ikinci sırada Atatürk, bayrak, kalabalık insan toplulukları gösterilerek birlik milli birlik duygusu verilmektedir. Üçüncü sırada ise 
çocukların, yaşlıların ve kadınların çokça yer verildiği sosyal haklara vurgu yapılmaktadır. Akşener en çok, kadın, çocuk ve yaşlı görüntüleri ile sosyal haklara, esnaf, çiftçi ve sanayi görüntüleri ile ekonomiye son olarak da 15 Temmuz Darbe girişimine yönelik görüntülerle iç politikaya ait konular öne çıkmaktadır. Siyasal reklam ve twitt kullanımı adayların kendi seçim stratejileri doğrultusunda kurguladıkları mesajları seçmene iletmek gibi aday kaynaklı çabaları ifade etmektedir. İzleyicilerin özellikle reklamlara maruz kalması, politik bilgi edinme etkinliğini önemli ölçüde arttırmaktadır (Kaid vd., 2007) Diğer taraftan kampanya gündeminin oluşturulmasında siyasal reklamların kullanımı seçim başarısı için önemli bir faktördür (Balcı ve Bal, 2007). Bu nedenle çalışmada reklam ve twitt paylaşımlarının kategori benzerliği aranmıştır. Erdoğan'ın siyasal reklamlar ve Twitter paylaşımlarının kategorik dağılımı arasında benzerlik yalnızca \%18 (değerler ve göç) düzeyindedir. Reklamlarda yer alan birlik beraberlik duygusu twitt paylaşımlarında da görülmektedir. İnce'nin \%9 (göç) ve Akşener'in \%18 (ekonomi ve iç politika) düzeyindedir. Benzerliklerin yüzdelik oranları incelendiğinde çok düşük olduğu görülmektedir. En yüksek oran Akşener'e aittir. Adayların siyasal reklam gündemi konuları ile Twitter paylaşımlarındaki gündem konuları arasında benzerlik olmaması kampanya başarısı için istenen bir sonuç olarak değerlendirilmemektedir.

Diğer taraftan adaylarla ilgili haberlerin sırası, ayrılan süre gibi unsurların kullanımı konunun önem derecesini belirlemektedir (Atabek, 1998), kamuoyunun gündemi ise medyanın konulara verdiği önemle şekillendirmektedir (Kuyucu, 2016). Medya gündem oluştururken politik gündemden etkilenmektedir ayrıca medya gündemleri kanaat önderlerinin kitlelerin fikirlerini yönlendirmesi sonucu kamu gündemini etkileyebilmektedir (McQuail ve Windahl, 2010). Kamu ve siyasal gündemi etkilemede önemli bir yere sahip olan medyada konularının önem derecesinin belirlenmesi, reklam ve twittlerin aksine o medya kuruluşunun yayın politikasına bağlıdır. Haber kanallarının seçim gündeminde adayları hangi gündem konuları ile öne çıkardığı kadar gündem sıralamasında hangi mecralardan etkilendiğini belirlemek de önemlidir. Bu nedenle siyasal reklam gündemi ile haber gündemi arasında benzerlik incelenmiştir. Siyasal reklamlar ve haber gündemi kategorisinde 
Erdoğan'ın yalnızca \%27 (ekonomi, bireysel özgürlükler ve eğitim kategorisinde), İnce'nin \%27 (ekonomi, değerler ve göç kategorisinde) oranında benzerlik taşıdığı ve Akşener'in siyasal reklamları ve haber kategori dağılımında hiç benzerlik olmadığı sonucu elde edilmiştir. Siyasal reklamlar ve haber konularının kategorik dağılımlarının yüzde oranları incelendiğinde benzerliğin çok düşük oranda olduğu görülmektedir. Ancak siyasal reklamlar ve Twitter paylaşımlarının kategorik dağılımı arasındaki benzerlikten daha yüksek orandadır.

Çalışmada elde edilen sonuçlar daha önceki çalışmaların aksine (Roberts ve McCombs, 1994; Escobar vd., 1998; Kim vd., 2016 ) adayların siyasal reklam gündeminin Twitter paylaşımlarının gündem konuları ve haberlerin gündem konuları ile benzerlik taşımadığı yönündedir. Ancak bu sonuç Sweetser vd.'nin (2008) siyasal reklamların haberleri üzerinde belirleyici olmadığı sonucu ile örtüşmektedir. Diğer taraftan Erdoğan'ın Twitter ve haber gündeminin kategorik benzerliğinin hiç olmadığı sonucu elde edilmiştir. İnce'nin \%9 (bireysel özgürlükler), Akşener'in \%45 (sosyal haklar, dış politika, bireysel özgürlükler, göç ve çevre) oranında benzerlik olduğu tespit edilmiştir. Akşener her iki iletişim aracını da paralel konu paylaşımı ile kullanmıştır. Dolayısıyla bu sonucun Sweetser vd. (2008) ve Vargo vd.'nin (2014) çalışma sonuçları ile örtüştüğü belirlenmiştir.

Çalışmada siyasal reklamlar, twittler ve haberlerde yer alan içeriklerin toplamında konu dağılımı analiz edilmiş ve tüm kategorik veriler içinde İnce ve Akşener'in sıralamasında \%72 oranında benzerliğin olduğu, Erdoğan ile diğer adaylar arasında gündem konusu benzerliğinin ise \%36 düzeyinde olduğu tespit edilmiştir.

Adayların siyasal reklam, haber ve twitt paylaşımlarındaki kategori benzerliği düşük düzeyde iken adaylar arasında benzer mecralarda benzer kategorilerin sıralamasının yer aldığı görülmektedir. Bu sonuç ile çalışma Sweetser vd.'nin (2008) adayların 2004 başkanlık seçimlerinde kullandıkları blogların gündem konuları ile örtüştügünü ortaya koyan çalışmanın sonuçları ile benzerlik taşımaktadır. Erdoğan ve Akşener'in Twitter paylaşımlarındaki konu dağılımları ile İnce ile Akşener'in haber kategorilerinin dağılımı arasındaki benzerlik oranı yüksektir. Benzer mecrada adaylar konu paylaşımlarını benzer oranda yapmıştır. Diğer taraftan bireysel özgürlükler, çevre ve göç konuları Erdoğan ve 
Akşener'in Twitter paylaşımlarında benzer olarak en son sırada gelmektedir. Yine diş politika ve sosyal haklar dışındaki konulara İnce ve Akşener'in haber konularında benzer sıralamada yer aldığı sonucu elde edilmiştir. Sosyal haklar Akşener için daha önceliklidir. Tüm adaylar içinde değerler ve ekonomi hep öncelikli, çevre ve göç konusu ise en son gündeme alınan konulardır.

Seçim kampanyalarında adaylar imaj oluşturmak kadar mevcut problemlere yönelik çözümleri seçmene aktarmak için reklam araçlarını kullanmaktadır. Seçim kampanyalarında siyasal reklamların başarısı hatırlatma ve farkındalık oluşturma kadar (Ghorpade, 1986, s. 24) adayın yaklaşımını seçmenleri ile paylaşmada ne derece yerinde kullanıldığ de ilişkilidir. Ancak Türkiye'de siyasal reklamlar yalnızca duygusal çekiciliklerin kullanıldığ 1 siyasal parti ya da aday imajına oluşturmak amacıyla yapılmaktadır. Toplumun gündeminde yer alan mevcut sorunlara yönelik adayın seçim önerilerini seçmenlerine taşımamaktadır. Oysa 1984'teki ABD'deki seçimlerde seçmen davranışını şekillendiren reklamlardaki çağrışım ve farkındalık oluşturma fonksiyonu iken (Ghorpade, 1986) 2004 seçimlerinde seçmenler Kerry'in mevcut sorunlar hakkında daha fazla bilgiyi reklamlarla sağlamaktadır (Kaid vd., 2007).

Siyasal reklam anlayışı dönüşüm yaşamaktadır. Dünyanın birçok ülkesinde siyasal kampanyalarda reklamlar diğer iletişim araçları ile bütünleşik olarak kulanılmaktadır. Yalnızca duygusal mesajlarla değil bilişsel düzeyde de seçmenlerle iletişim kurulmaktadır. Türkiye'de ise siyasal kampanyalar sistemli ve bütünleşik pazarlama anlayışından uzak yapılmaktadır. Siyasal kampanyaların hedeflenen başarıyı yakalaması için seçmen bilinçli seçim yapabilen bireyler olarak kabul edilmeli ve reklamlar aracılığı ile seçmene diğer iletişim araçları ile paralel konular aktarılmalıdır.

Çalışma adayların siyasal reklam, Twitter paylaşımları ve haber gündemi kullanılarak gündem konularının sıralamasının belirlenmesi ve adayların gündem konularının birbiri ile benzerliklerini ortaya koymak açısından önemlidir. Siyasal kampanya sürecinde adayların gündem konuları ile seçmenlerin gündem konuları arasındaki etkileşim ve cinsiyet, meslek grubu gibi değişkenlerin etkisi farklı bir araştırma konusunu oluşturmaktadır. 
EXTENDED ABSTRACT

\title{
The Similarity Analysis of Political Advertising, Twitter and News Agenda in the Context of 2018 Presidency Election
}

\author{
Emine Şahin - Özlem Duğan - Adil Bical \\ Gaziantep University - Uşak University - Anadolu University
}

In times of elections the candidates focus on political communication efforts and they bring some certain topics to their agenda in terms of their campaign strategies. From time to time media and public news shape the agenda of the candidates and at times media institutions create their news stories based on the public opinion and the candidates' agenda topics. In this sense the relationship between the agenda setting theory that is used for political communication endeavours and media and politics and indirectly the agenda of the society, scrutinizes in terms of the topics of these institutions' agenda and aims to reveal the effect of these on each other.

The Agenda Setting Theory was firstly introduced by Kurt Lang and Gladys E. Lang and it's other pioneers are American researchers Malcom McCombs and Donald Shaw (Yumlu, 1994, s. 96; Yaşin, 2008, s.5; Yaylagül, 2014, s.79). The first study was McCombs and Shaw's (1972) that aimed to measure the power of mass media in setting agenda for the 1968 Presidency elections in the United States of America sample, many studies were conducted since then. McCombs and Shaw who ensured that the theory is developed to today's form defend the judgement that individuals create their own field of interest by evaluating the information they gained through mass media and forming an opinion regarding the importance of events of news for the society (Güngör, 2011, s. 98).

By using Robert and McCombs' Agenda Setting Theory, in this study which is conducted in order to reveal the similarities of issue agenda during the 2018 presidential election candidates' political ads content, their Twitter posts and the news coverage aired in the news websites; the political advertisements, Twitter posts and the news of the most popular news websites of the candidates which are Recep Tayyip Erdoğan, Muharrem 
Ince and Meral Akşener are examined. Within the scope of this study, 50 commercial films; 16 of Erdoğan, 16 of Ince and 18 of Akşener were examined; also a total of 1,417 Twitter posts; Erdoğan's 238, İnce's 436 and Akşener's 743 Tweets were studied. Lastly, Erdoğan's 66, Ince's 60 and Akşener's 96, a total of 222 news story were included in the investigation. Moreover, at the last phase of the study Erdoğan's 4224, Ince's 3167 and Akşener's 4232 categorical data were put under evaluation ( $N=11623)$.

In the study, qualitative research design is chosen and with Nvivo software and encoders content analysis is performed used in terms of categorical words and timing; thus searching answers for research questions. The examined point is the similarities between the candidates' agenda issues in their political advertisements and agenda topics of the news that are aired in news websites; the similarities between the candidates' agenda topics in their political ads and the agenda topics of their Twitter posts and lastly the similarities between the candidates' agenda topics of their general statements.

The result of the study reveals that when the percentage of the similarities between political ads agenda coverage and Twitter posts agenda coverage is very low. The highest percentage is Akşener's. When the categorical distribution percentages of political ads and agenda coverage are examined it is observed that the similarity is very low. However the percentage is higher than the similarities between political ads and Twitter posts' categorical distribution.

The results of the study shows that contrary to previous studies regarding political advert agenda coverage (Roberts ve McCombs, 1994; Escobar et al., 1998; Kim et al., 2016) there is no similarity between the Twitter posts of the candidates and the agenda coverage of the news. On the other hand when the categorical similarity of Twitter and news agenda there is no categorical similarity between Erdoğan's Twitter posts and the news agenda. Some similarity was detected in İnce's posts 9\% (individual freedom), Akşener's posts \%45 (social rights, foreign policy, individual freedom, immigration and environment). Akşener used both pulpits for sharing parallel issues. Thereby it is determined that this outcome overlaps with Sweetser et al. (2008) and Vargo et al.'s (2014) research conclusions. 
In the study the topics of political ads, tweets and news coverage were analysed and among all categories it is determined that there is $72 \%$ similarity between İnce and Akşener's arrangement, and the agenda similarity percentage between Erdoğan and the other candidates is at 36\% level.

While the category similarity percentage is low for the candidates' political ads, news and twitter posts, it is observed that there is similar category arrangement for similar channels between candidates. This conclusion show some similarity to the results of Sweetser et al (2008) study which reveals that the candidates' blogs that they used for 2004 presidency elections and the agenda coverage overlaps. The percentage of similarity between Erdoğan and Akşener' Twitter posts coverage and İnce and Akşener's news categories distribution is high. For all the candidates the prior topics are values and economy and least mentioned topics are environment and immigration.

This study puts forward important outcomes in terms of determining the order of the agenda coverage by political ads, Twitter posts and news agenda and revealing the similarities between the candidates' agenda coverage with each other. During the political campaign the interaction between the candidates' and voters' agenda and the effect of variables like gender and profession constitutes the topic of another study.

\section{Kaynakça / References}

Acar-Şentürk, Z. ve Tos, O.(2018). İkinci düzey gündem belirleme araştırması: 29 Ekim 2018 günü ulusal gazeteler örneği. Akademik Sosyal Araştırmalar Dergisi, 6(85), 81-103.

Arklan, Ü. ve Karakoç, E. (2015). Medyanın genel ve siyasal gündeme ilişkin bilgi edinme aracı olarak kullanımı: Görgül bir araştırma. Selçuk Üniversitesi Türkiyat Araştırmaları Dergisi, 1(33), 325-363.

Aslan, E. (2014). Marka 2.0 stratejileri bağlamında global markaların sosyal medyada gündem belirlemesi: Markaları 2.0 gündemi (Yayınlanmamış Doktora Tezi), Gazi Üniversitesi, Ankara.

Aslan, E.-Tavşancıl, E. (2001). İ̧̧erik analiz ve uygulama örnekleri. İstanbul: Epsilon.

Atabek, N. (1998). Gündem belirleme yaklaşımı. İstanbul Üniversitesi İletişim Fakültesi Dergisi, 7, 155-174. 
Balc1, Ş. ve Bal, E. (2007). Genel Seçimleri'nde AKP ve CHP Reklamları: Karşılaştırmalı bir analiz. Selçuk Üniversitesi İletişim Fakültesi Dergisi, 33, 5-28.

Balcı, Ş. ve Damlapınar, Z., Pınarbaşı, T., E., Astam, F., K., (2016). Siyasal bilgilenmede medyanın rolü ve etkinliği: Üniversite öğrencileri araştırmasi. The Journal of Academic Social Science Studies, 53, 111126.

Bayram, Y. (2017). Gençlerin siyaset gündemi konularına yaklaşımı ve medya kullanım alışkanlıklarının belirlenmesi: 15 temmuz darbe girişimi örnek olayı. OPUS - Uluslararası Toplum Araştırmaları Dergisi, 7(13), 887-911. DOI: 10.26466/opus.359703

Becker , L.,ve McCombs , M. (1978). The roles of the press in determining voter reactions to presidential primaries. Human Communication Research, 4, 301-307.

Bozkanat, E. (2013). Gündem kurma perspektifinden algı yönlendirme alkol düzenlemesi yasası örneği. Yayınlanmamış Yüksek Lisans Tezi, Gazi Üniversitesi Sosyal Bilimler Enstitüsü, Ankara.

Freelon, D. (2013). ReCal OIR: Ordinal, interval and ratio intercoder reliability as a web service. International Journal of Internet Science, 8(1), 10-16.

Geçer, E. ve Şimşek. B.Ş. (2017). Beyaz perdede gündem belirleme: "Başkanın Adamları" ve "Kriz Bizim İşimiz" filmleri örnekliği. Selçuk İletişim Dergisi, 10 (1), 335-356

Geçtiğimiz Hafta Yağmak Bilmeyen ‘Dolu’ İçin Atılan Birbirinden Komik Tweet'ler (2 Tem. 2018). 8 Ekim 2018 tarihinde https://www.torik.tv/listeler/gectigimiz-hafta-yagmak-bilmeyendolu-icin-atilan-birbirinden-komik-tweetler/ adresinden erişildi.

Ghorpade, S. (1986). Agenda setting: A test of advertising's neglected function. Journal of Advertising Research, 23-27.

Gökçe, O. (2003). İçerik analizi, kuramsal ve pratik bilgiler. Siyasal Kitabevi: Ankara.

Güneş, A. (2014). Gündem belirleme teorisi bağlamında 30 mart 2014 yerel seçimlerinin basında sunumu: AKP ve CHP örneği. The Turkish Online Journal of Design, Art and Communication -TOJDAC, 4(2), 115.

Güngör, N. (2011). İletişim kuramlar ve yaklaşım. Ankara: Siyasal Kitabevi. 
Güran, M. S.ve Özarslan, H. (2013). Çerçeveleme teorisinin halkla ilişkilerde kullanımı. Selçuk Üniversitesi Türkiyat Araştırmaları Dergisi, 1(34), 299-314.

Güz, N. (2005). Haberde yönlendirme ve kamuoyu araştırmaları. Ankara: Nobel Dağıtım.

Hawks, B. B. (2002). Agenda-setting research. İstanbulüniversitesi İletişim Dergisi, 13, 491-499.

Hazaparu M. A. (2014). Setting the agenda in advertising: Understanding ethical dilemmas from a communicative perspective.Comunicação e Sociedade, 25, 328 - 342, 10.17231/comsoc.25, DOI: 10.17231/comsoc. $25(2014) .1878$

Jasperson, A.E., Shah, D.V.,Watts, M., Faber,R. J. veFan, D.P.(1998) Framing and the public agenda: Media effects on the importance of the federal budgetdeficit, Political Communication, 15:2, 205-224, DOI: 10.1080/10584609809342366

Kaid, L.L. ve Johnston, A. (1991). Negative versus positive television advertising in U.S.presidential campaigns, 1960-1988. Journal of Communication, 41 (3), 53-64.

Kaid, L.L., Postelnicu, M., Landreville, K., Yun H.J. ve LeGrange, A.G. (2007). The effects of political advertising on young voters. American Behavioral Scientist, 50(9), 1137-1151 DOI: 10.1177/0002764207300039

Kim, Y., Gonzenbach, W.J., Vargo, C.J., ve Kim, Y. (2016). First and second levels of intermedia agenda setting: Political advertising, newspapers, and twitter during the 2012 US Presidential Election. International Journal of Communication, 10, 4550-4569.

Krippendorff, K.(2004). Content analysis an introduction to its methodology. Sage Publications: London

Koçak, A. ve Arun, Ö. (2006). İçerik analizi çalışmalarında örneklem sorunu. Selçuk İletişim Dergisi, 4(3), 21-28.

Kuyucu, M. (2016). Gündem belirleme teorisi bağlamında radyo mecrasının müzik kamuoyunu belirleme gücü. 3. International Conference On Education Social Sciences and Humanities, 23-25 May 2016, İstanbul-Turkey. 326-346. 
Landis, J. R. and Koch, G. G. (1977). The measurement of observer agreement for categorical data. Biometrics, 33(1), 159-174. Stable URL: https://www.jstor.org/stable/2529310Accessed: 28-12-2018 18:03 UTC

Lilleker, D. G. (2013). Siyasal iletişim: Temel kavramlar. (ed. Y. Devran, A. Nas, B. Ekşi ve Y.Göksun). (A. Altın, A. Nas, B. Ekşi, K. Bölükbaş, K. Mammadlı, S.Midilli, F. Mustafa Tinç, S., N. Mustafa ve Y. Göksun, çev.). İstanbul: Kaknüs Yayınları.(Eserin orijinali 2006'da yayımlanmıştır).

Lopez-Escobar, E., Llamas, J. P., McCombs, M., veF.R. Lennon (1998). Two levels of agenda setting among advertising and news in the 1995) Spanish elections. Political Communication, 15(2), 225-238, DOI: 10.1080/10584609809342367

McCombs, M. E. ve Yüksel, E. (2001). The economic privatization issue in Turkey a four-part investigation of agenda setting theory. Uluslararası İletişim Sempozyumu "Medyanın Manipülasyon Gücü" içinde (148-161), AnadoluÜniversitesi, Eskişehir.

Mcquail, D. ve Windahl, S. (2010). İletişim modelleri: Kitle iletişim çalışmalarında(Çev: Konca Yumlu). Üçüncü Baskı, Ankara: İmge Kitabevi

McCombs , M. E. ve Shaw, D.L . (1972). American association for public opinion research. The Public Opinion Quarterly, 36(2), 176-187.

Meirick, P. C., Nisbett, G. S., Harvell-Bowman, L. A., Harrison, K. J., Jefferson, M. D., Kim, T-S ve Pfau, M.W. (2018). To tell the truth: adwatch coverage, ad tone, and the accuracy of political advertising. Political Communication,35(3), 450-469, DOI: 10.1080/10584609.2017.1414089.

Miller, R., E. ve Wanta, W. (1996). Race as a variable in agenda setting.Journalism and Mass Communication, 73(4), 913-921.

Min, Y. (2003). Media agenda -setting and its electoral consequences: A study of political advertising, the new media and public in 2002 primary election for Texas Governor. ProQuest Dissertations and Theses; ProQuest Dissertations ve Theses Global, ABD: Texas University.

Rahn, W. M.,ve Hirshorn, R. M. (1999). Political advertising and public mood: A study of children'spolitical orientations. Political Communication, 16, 387-407. 
Roberts, M.,ve McCombs, M. (1994). Agenda setting and politicaladvertising: Origins of the news agenda., Political Communication, 11:3, 249262, DOI:10.1080/10584609.1994.9963030

Roberts, M., Wanta, W., ve Dzwo, T. H. D. (2002). Agenda setting and issue salience online.Communication Research, 29(4), 452-465. Doi:10.1177/0093650202029004004

Seçim Sonuçları, (Haziran, 2018).21 Kasım 2018 tarihinde http://www.internethaber.com/secim-sonuclari/2018-secim-sonuclari adresinden erişildi.

Sutherland, M. and Galloway J. (1981). Role of advertising: Persuasion or agenda setting. Journal of Advertising Research, 21(5), 25-29.

Sweetser, K. D., Golan, G.J.ve Wanta, W. (2008). Intermedia agenda setting in television, advertising, and blogs during the 2004 election.Mass Communication ve Society, 11(2), 197-216, DOI: 10.1080/15205430701590267.

Şahin, E. ve Acar-Şentürk, Z.(2018). Gündem oluşturma teorisi bağlamında özel günleri konu alan reklamların analizi. International Journal of Social Sciences and Education Research, 4(4), 698-720.

Tavşancıl, E. ve Aslan, E. (2001). Sözel, yazılı ve diğer materyaller için içerik analizi ve uygulama örnekleri. İstanbul: Epsilon Yayınevi.

Terkan, B. (2005). Gündem belirleme, medya ve siyasal gündem üzerine bir çalışma. Konya: Tablet Yayınları.

Terkan, B. (2007). Basın ve siyaset ilişkisinin gündem belirleme modeli çerçevesinde bir analizi. Selçuk Üniversitesi Sosyal Bilimler Enstitüsü Dergisi, 6(17), 561-584.

Tokgöz, O. (2014). Siyasal iletişimi anlamak. Ankara: İmge Kitabevi,

Toruk, İ. (2008). Üniversite gençliğinin medya kullanım alışkanlıkları üzerine bir analiz. Selçuk Üniversitesi Sosyal Bilimler Dergisi, 19, 475488.

Top Sites in Turkey (Ekim 2018). 15 Ekim 2018 tarihinde https://www.alexa.com/topsites/countries/TR sitesinden erişildi.

Vargo, C. J., Guo, L., McCombs, M., ve Shaw, D. L. (2014). Network issue agendas on twitter during the 2012 u.s. presidential election. Journal of Communication, 64, 296-316.doi:10.1111/jcom.12089 
van Praag, Jr. , P. ve van der Eijk, C. (1998). News content and effects in anhistoric campaign. Political Communication, 15(2), 165-183, doi.org/10.1080/10584609809342364

Vodinalı, S. ve Çötak, N.A. (2015). Siyasal propaganda bağlamında siyasal reklamlar: 2015 Türkiye genel seçimlerinde AKP/CHP/MHP Partileri TV reklamları üzerine bir değerlendirme. Global Media Journal TR Edition, 6(11), 497-531.

Woodly, D.(2007). New competencies in democratic communication? Blogs, agenda setting and political participation. Public Choice, 134, 109-123, Doi: 10.1007/s11127-007-9204-7

Yakubu, B. A. (2015). İkinci aşama gündem belirleme çalışması: 2012 Gana genel seçimlerindeki siyasal kampanyalarn gazete haberlerinde çerçevelenmesi.Yayımlanmamış Yüksek Lisans Tezi, Anadolu Üniversitesi Sosyal BilimlerEnstitüsü, Eskişehir.

Yaşin, C. (Der.) (2008). Gündem belirleme kuram ve araştırmalarmm tarihsel gelişimi, gündem belirleme kuram ve araştırmaları. Ankara: Yargı Yayınevi.

Yaylagül, L. (2014).Kitle iletişim kuramları: egemen ve eleştirel yaklaşımlar. Ankara: Dipnot Yayınları.

Yumlu, K. (1994). Kitle iletişim kuram ve araştırmaları. İzmir: NamYayınları.

Yüksel, E. (2007). Kamuoyu oluşturma ve gündem belirleme kavramları nerede kesişmekte, nerede ayrılmaktadır? Sosyal Bilimler Dergisi, 1, 571-586.

Yüksel, E. (2001).Medyanın gündem belirleme gücü. Konya: Çizgi Kitabevi.

\section{Kaynakça Bilgisi / Citation Information}

Şahin E., Duğan, Ö. ve Bical A. (2019). 2018 Cumhurbaşkanlığı seçimleri bağlamında siyasal reklamlar, twitter ve haber gündemi benzerlik analizi. OPUS-Uluslararası Toplum AraştırmalarıDergisi, 10(17), 1262-1303. DOI: 10.26466/opus.522288 